Article

\title{
Energetic, Economic and Environmental (3E) Assessment and Design of Solar-Powered HVAC Systems in Pakistan
}

\author{
Sajid Mehmood ${ }^{1,2}$, Serguey A. Maximov ${ }^{1}$, Hannah Chalmers ${ }^{1}$ and Daniel Friedrich ${ }^{1, *(D)}$ \\ 1 School of Engineering, Institute for Energy Systems, The University of Edinburgh, Colin Maclaurin Road, \\ Edinburgh EH93DW, UK; S.Mehmood@ed.ac.uk (S.M.); Serguey.Maximov@ed.ac.uk (S.A.M.); \\ Hannah.Chalmers@ed.ac.uk (H.C.) \\ 2 Department of Mechanical, Mechatronics and Manufacturing Engineering (New Campus), University of \\ Engineering \& Technology, Lahore 54000, Pakistan \\ * Correspondence: D.Friedrich@ed.ac.uk; Tel.: +44-(0)131-6505662
}

Received: 29 June 2020; Accepted: 19 August 2020; Published: 21 August 2020

check for updates

\begin{abstract}
Rapid urbanization, global warming and enhanced quality of life have significantly increased the demand of indoor thermal comfort and air conditioning systems are not a luxury anymore, but a necessity. In order to fulfil this need, it is imperative to develop affordable and environmentally friendly cooling solutions for buildings. In this work, the 3E performance (energetic, economic and environmental) of electrically driven water-cooled vapour compression systems and thermally (solar) driven vapour absorption cooling systems are evaluated and the parameters affecting the performance of solar-driven vapour absorption systems are investigated. The energy simulation software TRNSYS is used to simulate the performance of both systems in order to fulfil the cooling needs of an industrial manufacturing building for the typical climate conditions for Lahore, Pakistan. Primary energy saving, initial investment, operational cost, and carbon footprint indices are used to analyse the performance of both systems. In addition, a parametric code is written in Python and linked with TRNSYS to perform a parametric study to investigate the effects of various parameters such as solar field size, storage tank volume, optimum annual and monthly collector angles, and flow rate in the solar field on the solar-driven vapour absorption chiller performance. The results reveal that around 5\% more energy can be absorbed per collector surface area by changing the solar tilt angle on a monthly basis compared to one fixed angle. The analysis shows that electrically driven vapour compression-based cooling systems have much higher running cost and are potentially hazardous for the environment but have lower capital costs. On the other hand, solar thermal systems have lower running costs and emissions but require further reductions in the capital costs or government subsidies to make them viable.
\end{abstract}

Keywords: solar thermal driven absorption chiller; optimum collector tilt angle; TRNSYS; parametric study; heating ventilation \& air conditioning; solar cooling

\section{Introduction}

Increasing energy demand and environmental pollution are among the major challenges for the world and research is underway to develop more environmentally friendly systems. Currently most of the world energy is provided by burning fossil fuels which results in large $\mathrm{CO}_{2}$ emissions [1]. For example, Pakistan covered 54\% of its total energy requirements by burning imported fossil fuels like natural gas and oil [2], which presents a significant burden on the national finances [3]. In addition, the country is still facing a $4000 \mathrm{MW}$ [2] energy shortfall in the peak summer season due to high demand for electrically driven space cooling. While energy consumption is directly linked to level of 
development, it is important to decouple them and to develop lower carbon technology alternatives [4]. Among the South Asian countries, Pakistan is strongly affected by global warming and faces severe energy crises in peak summer seasons. It is forecasted that the huge investment in China's "belt and road initiative" will have many positive aspects for country development but will substantially increase the greenhouse gas emissions (GHG) as well [5]. Energy consumption in Pakistan is increasing by around $8 \%$ [6] per year and a large part of this increase is due to cooling needs in the peak summer season.

People spent up to $80 \%$ of their time indoors [7] and in the industrialized world, energy consumption in the building sector accounts for around $40 \%$ of the total world energy demand [8]. This is mainly used to maintain a comfortable temperature inside buildings. Population growth, global warming and enhanced quality of life (high internal gains from equipment inside buildings and lighting, increased occupant comfort demands, architectural characteristics, such as growing popularity of glass buildings and window to wall ratio) have significantly increased the energy demand of air conditioning. The amount of energy spent for space cooling has increased by $4 \%$ annually since 1990 and it is forecasted that the energy demand for all cooling applications will increase by $15 \%$ by 2050 [9]. Reducing the energy consumption in the building sector without compromising on occupants' comfort while fulfilling heating, ventilation and air conditioning (HVAC) energy demand from renewable resources like solar could have environmental and financial benefits. To achieve these benefits, it is essential to evaluate and improve the feasibility of solar energy utilization for cooling applications, which could tackle the energy crises during peak summer season and utilize local renewable resources to reduce the import and associated costs of fossil fuels.

Based on thermodynamic principles, a cooling effect can be produced either with electrically driven or thermally driven cycles [10]. Vapour Compression Cycle (VCC) systems are mostly used to fulfill cooling demands but rely on an electrically driven compressor and contribute around $10 \%$ of global GHG emissions [9]. The market share of VCC-based technology is around 80\% [9] despite the large carbon footprint and often hazardous refrigerants. Most of the refrigerants used in these cooling systems exhibit significant global warming potential and also contribute to ozone depletion. On the other hand, thermally driven cooling systems are based on four different technologies: vapour absorption cycle, vapour adsorption cycle, desiccant cooling system and ejector cooling cycle [10]. Of these, vapour Absorption Cooling Systems (ACS) are most widely used due to high performance and technical maturity [11]. The source of heat to operate ACS can be solar energy, industrial exhaust gases or fossil fuels. Among the different heat sources, solar thermal driven ACS are under rapid development and are a promising technology to provide sustainable peak summer cooling due to the coincidence of cooling demand and solar irradiance. According to the International Energy Agency (IEA), it is expected that solar cooling will have a potential market of 417 TWh per year in 2050 [12]. Pakistan has a high annual global solar irradiance of $2071 \mathrm{kWh} / \mathrm{m}^{2}$ [13] and around 10-12 sunshine hours per day, which makes it attractive for solar-driven cooling applications.

Most of the studies found in the literature are based on energetic performance of vapour absorption chillers, while the evaluation of economic and environmental performance of solar-driven ACS are relatively unexplored, particularly for the climate and conditions of Pakistan. A few studies related to solar-driven absorption chillers and different types of solar collectors are summarized here. Different types of collectors are available to capture solar energy and to convert it into thermal energy at different temperatures. Mostly stationary (non-concentrating) collectors (evacuated tube collector or flat plate collector) are used to harness solar energy to operate single effect chillers [14], while concentrating collectors (e.g., parabolic trough collector) were used by $[15,16]$ to achieve the higher temperature required to operate multi-effect absorption chillers. Photovoltaic thermal collectors [17] combine photovoltaic and thermal collectors and provide both heat and electricity. Solar tracking systems (single axis or double axis tracking) are used to enhance the annual efficiency of the collector. The performance of all these collectors depends on solar irradiance and local climate conditions such as humidity and temperature. A review of different types of solar collectors and cooling technologies was conducted by Shirazi et al. [8]. Buonomano et al. [18] used stationary flat plate collectors to 
drive double effect chillers and compared this technology with concentrating collectors. Xu et al. [19] analysed single, double and variable effect chillers with Lithium bromide(LiBr)-water as a working pair. They found that the variable effect chiller achieved higher solar fraction and low auxiliary heat input. Gomri et al. [20] simulated solar ACS with natural gas as an auxiliary heat source in times of low solar irradiance. They discussed coefficient of performance (COP) of the refrigeration unit, exergy efficiency with varying generator inlet temperature and reducing condenser temperature. A configuration-based model of solar assisted ACS was carried out by [21] to fulfill cooling load requirement for an education building.

The performance and economic benefits of solar-driven ACS vary based on many factors such as weather, location, cost of components and system design [22]. The climate of Pakistan is hot and humid with a prolonged summer season adversely affected by global warming and people using VCC cooling systems which contribute to GHG emissions. The government of Pakistan is encouraging people through tax incentives to use solar energy to reduce GHG emissions [23]. While thermally driven cooling systems have significant potential to reduce the use of fossil fuels and consequently associated GHG emissions, they need to be carefully designed to provide both environmental and economic benefits. Considering this fact, there are only a few studies that compare electrically and solar thermal driven cooling systems simultaneously on their energy, economic and environmental (3E) performance. The performance depends critically on local weather conditions and costs of ACS and VCC system components, and to the authors' knowledge, there is not a single study available for the hot climate of Pakistan based on 3E assessment. Studies on evacuated tube solar collector tilt angle adjustment for Pakistan are also unexplored, although the country has huge potential for solar energy.

In this work, the comparative performance of vapour compression and solar assisted vapour absorption cooling systems were compared based on energetic, economic and environmental performance. The objective of this work was to compare two cooling technologies for the same chosen cooling capacity based on energy, economic and environmental indices; an electrically driven water-cooled vapour compression cycle chiller and a solar thermal driven vapour absorption cooling system. In addition, this study discusses the parameters affecting the performance of solar-driven vapour absorption chillers.

\section{Working Principle and Description of Two Cooling Systems}

This section presents the working principles of the solar-driven vapour absorption cycle and conventional vapour compression cycle.

\subsection{Conventional Vapour Compression Cycle}

Figure 1 shows the schematic of the conventional VCC when a mechanical compressor is used. The refrigerant is passed as low-pressure gas to an electrically driven compressor. The electrically driven compressor turns it into a high-pressure gas before it goes to the condenser. In the condenser, the refrigerant exchanges heat with water and condenses into a liquid state. The condensed refrigerant is then passed through an expansion valve which reduces its pressure. Finally, the low-pressure refrigerant is evaporated in the evaporator to produce the cooling effect and closes the cycle. To remove heat from the condenser, either air or water can be used. In this study, we used a water-cooled condenser due to its higher specific heat capacity as compared to air, which results in higher chiller performance. 


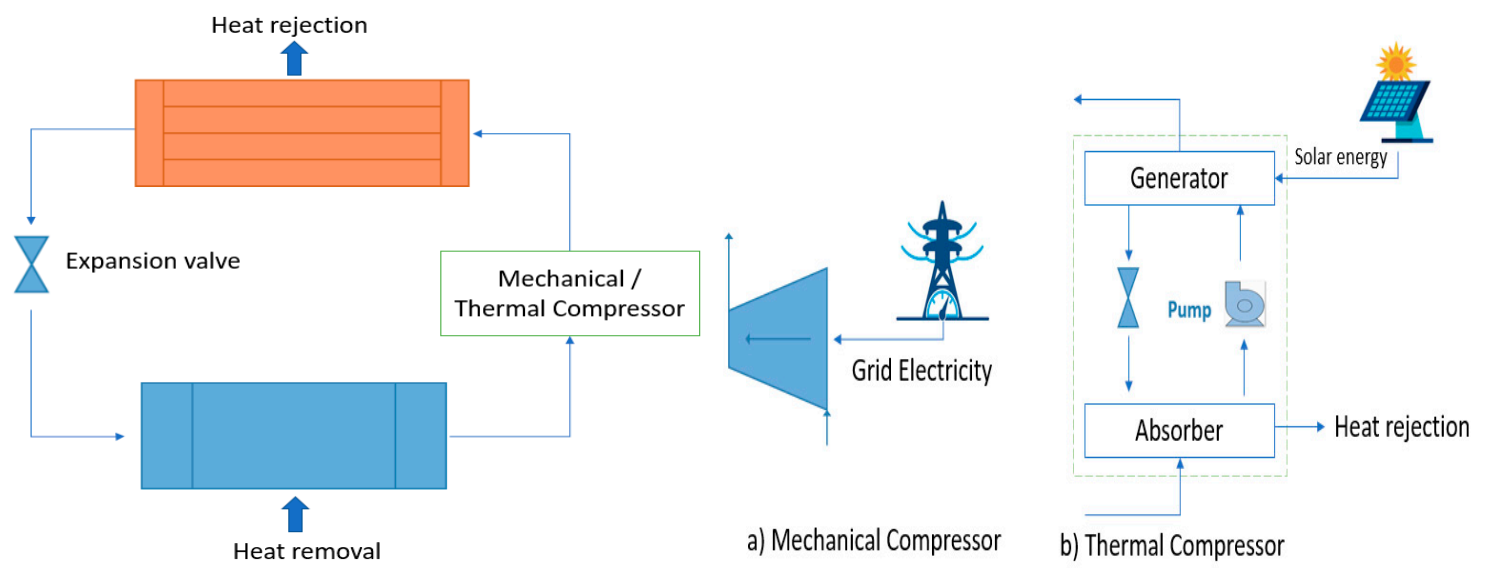

Figure 1. Schematic diagram of the conventional vapour compression cycle and the solar-driven vapour absorption cycle.

\subsection{Solar-Driven Vapour Absorption Cycle}

The schematic of the vapour absorption cycle is shown in Figure 1 in which the electrically driven compressor of the VCC is replaced by a thermal compressor which consists of a generator, solution pump and an absorber unit. The refrigerant (typically water) returns from the evaporator to the absorber section where it is absorbed in Lithium bromide $(\mathrm{LiBr})$ which has a strong affinity to absorb water. Once the LiBr mixes with water, a pump moves this LiBr-water mixture to the generator section where heat from solar energy is used to desorb water from this solution. Due to the different boiling points of water and $\mathrm{LiBr}$, water evaporates earlier and flows to the condenser. The liquid $\mathrm{LiBr}$ is returned back to the absorber section to absorb water for the next cycle. The evaporated refrigerant (water) then follows the standard refrigeration cycle (condenser, expansion valve and evaporator). To dissipate heat from the absorber and condenser, air or water can be used.

\section{Simulation Methodology}

The methodology employed in this work is shown in Figure 2. We used the energy simulation software TRNSYS which is a well known, flexible graphical-based simulation software widely used by researchers in the energy simulation community to model and simulate the transient behavior of energy systems [24]. This software solves differential equations generated from the system configuration with the modified Euler method and uses a successive iteration method to solve the non-linear equations for each component. The building geometry is defined in SketchUp which is widely used in creating 3D models of architectural drawings, interior design and in other civil and mechanical engineering applications [25]. We used the TRNSYS 3D plugin for SketchUp to create a dynamic 3D-building model. TRNSYS 3D zones are different from SketchUp zones, particularly because TRNSYS 3D zones are used to simulate the dynamic flow of energy. The geometrical characteristics of the building zones of the SketchUp model were imported into the TRNSYS TRNBuild software. The important building envelope (walls, windows, roof) characteristics, internal gains (light, equipment and occupants) and their variability over time were considered and incorporated in the building model. Building characteristics design parameters for indoor comfort are tabulated in Table 1. Finally, TRNSYS simulation studio was used to calculate the cooling load profile for a typical metrological year weather data for Lahore, Pakistan. To fulfil daily cooling load demand and to make a 3E assessment, two models were developed, i.e., solar assisted vapour absorption cooling system (ACS) and water-cooled electrically driven VCC, for an industrial building located in Lahore, Pakistan as shown in Figures 3 and 4, respectively. To analyse the parameters affecting the performance of solar-driven absorption chillers, a parametric study was performed over the collector area, flow rate in the collector loop, collector tilt angle, collector azimuthal angle and storage tank volume to determine optimum values. We linked the TRNSYS simulation to Python to perform the parametric study. 
The Python script modifies the TRNSYS deck file, runs the simulation and compiles the results of each simulation as shown in Figure 2.

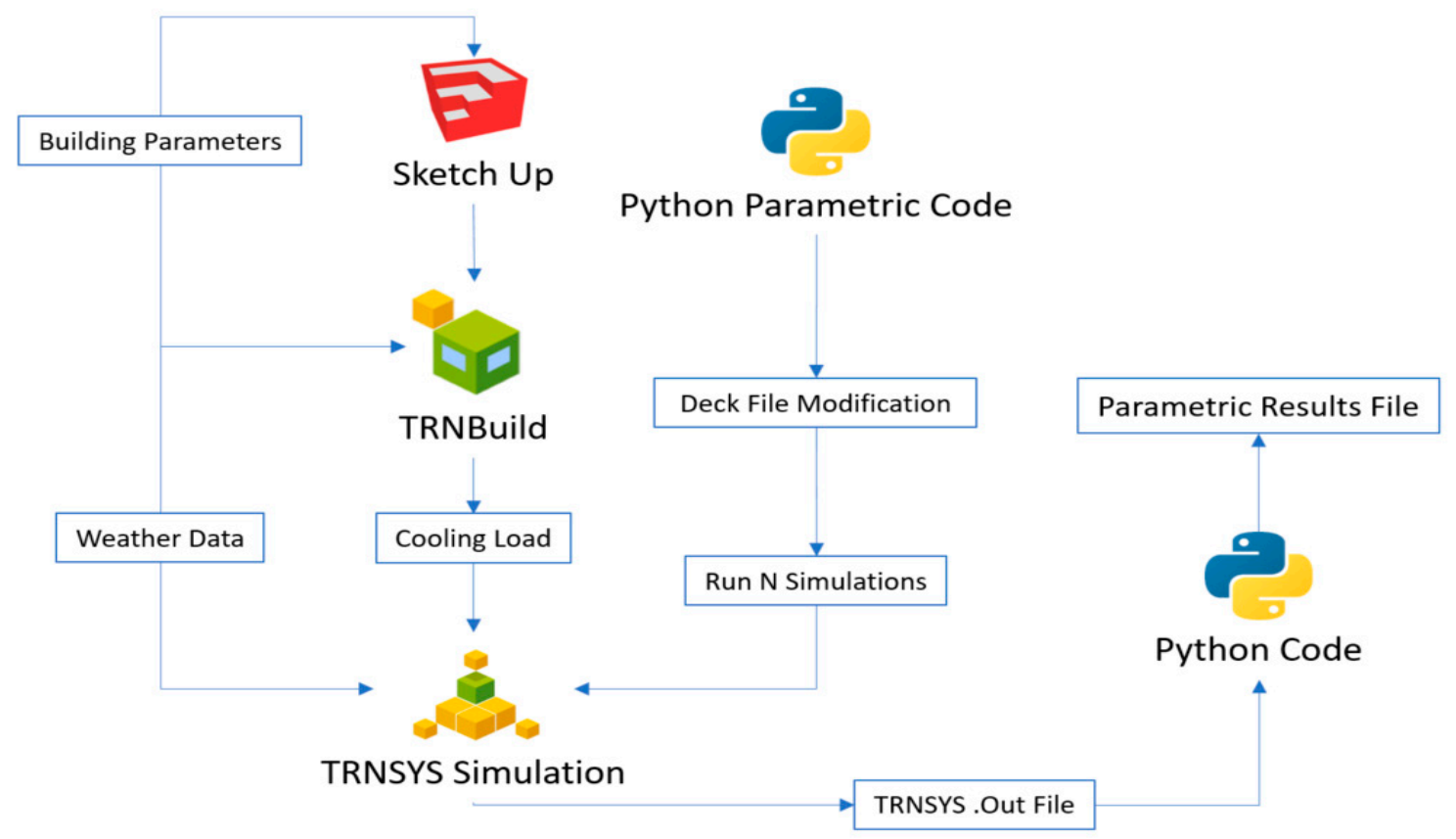

Figure 2. Simulation and parametric study methodology.

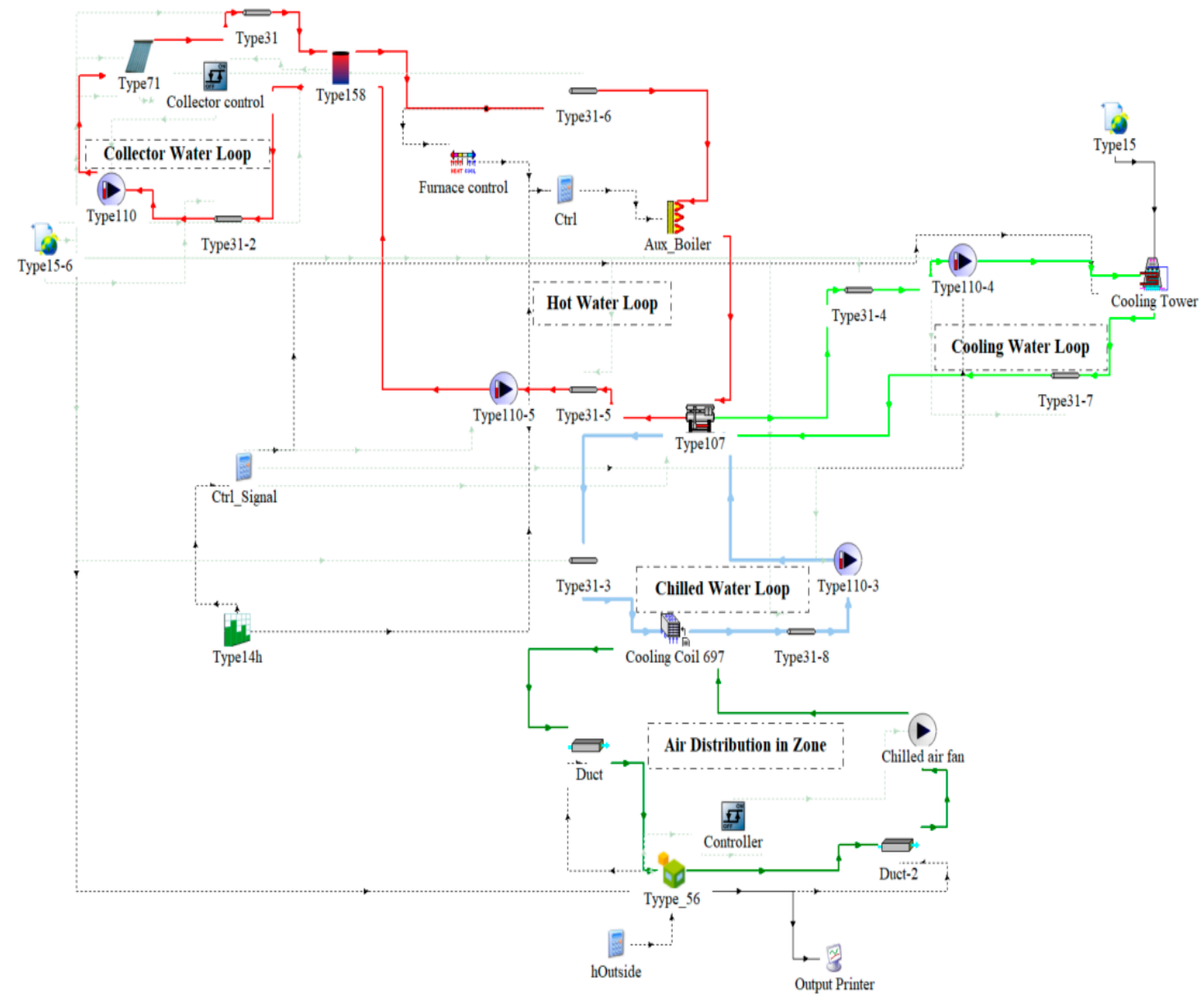

Figure 3. Solar absorption cooling system simulated in TRNSYS. 


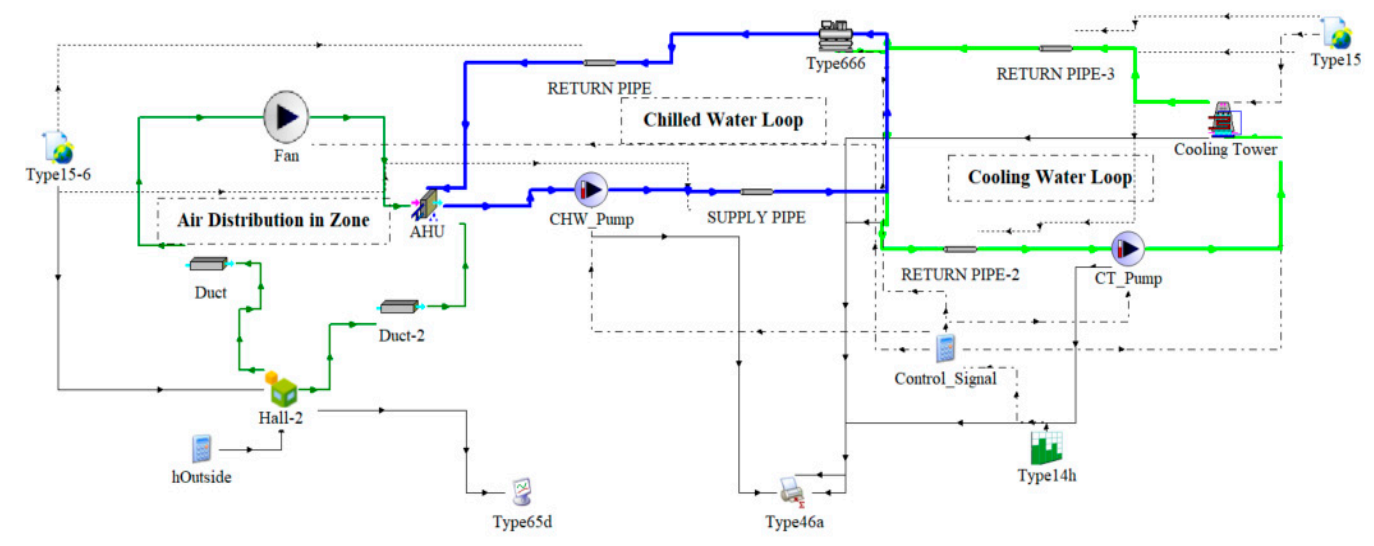

Figure 4. Water-cooled vapour compression cooling system simulated in TRNSYS.

Table 1. Building envelop characteristics and design cooling load conditions.

\begin{tabular}{cccccc}
\hline Parameter & \multicolumn{2}{c}{$\begin{array}{c}\text { Comfort \& Gains } \\
\text { Unit Amount }\end{array}$} & Parameter & $\begin{array}{c}\text { Wall Layers \& Windows } \\
\text { Unit Amount }\end{array}$ \\
\hline Temperature set point & ${ }^{\circ} \mathrm{C}$ & 26 & $\mathrm{U}_{\text {wall }}$ & $\mathrm{W} / \mathrm{m}^{2} \mathrm{~K}$ & 2.003 \\
Relative Humidity set point & $\%$ & 50 & Wall thickness & $\mathrm{m}$ & 0.268 \\
Air change rate & $\mathrm{vol} . / \mathrm{h}$ & 2 & $\mathrm{U}_{\text {roof }}$ & $\mathrm{W} / \mathrm{m}^{2} \mathrm{~K}$ & 0.535 \\
Infiltration & vol./h & 0.6 & Roof thickness & $\mathrm{m}$ & 0.052 \\
Lighting & $\mathrm{W} / \mathrm{m}^{2}$ & 1.1 & U value, window & $\mathrm{W} / \mathrm{m}^{2} \mathrm{~K}$ & 1.1 \\
Equipment & $\mathrm{kW}$ & 340 & G value, window & $\% / 100$ & 0.62 \\
Occupants & no. & 100 & Roof solar absorptance & $\% / 100$ & 0.1 \\
$\mathrm{U}_{\text {floor }}$ & $\mathrm{W} / \mathrm{m}^{2} \mathrm{~K}$ & 0.336 & $\mathrm{U}_{\text {skylights }}$ & $\mathrm{W} / \mathrm{m}^{2} \mathrm{~K}$ & 5.69 \\
\hline
\end{tabular}

\subsection{General Approach}

As shown in Figure 3, the solar-driven ACS consists of four water loops, i.e., solar collector loop, hot water (HW) loop, cooling water (CW) loop and chilled water (CHW) loop. Water passes through the collectors (Type 71) and is heated before being passed to a storage tank (Type 158). For smooth operation of the chiller, the hot water is stored in a thermally stratified storage tank. To control the outlet temperature of the collector, a feedback controller was used to adjust the fluid flow rate of a variable speed pump. The pump was controlled by a differential controller to operate only when there is at least an $8{ }^{\circ} \mathrm{C}$ temperature rise from collector; this saves electrical energy during the night and in times of low solar irradiance. An auxiliary gas boiler was installed in the hot water loop to increase the temperature of hot water to the absorption chiller (Type 107) set point if solar irradiance was insufficient to achieve that temperature. To produce the cooling effect as described in Section 2.2, this hot water acts as a heat source for the desorption of water and LiBr. The chilled water is then passed through an air handling unit (cooling coil 697) to fulfil the cooling load requirements of the building. A fan coil air handling unit was used to exchange the heat of chilled water with zone air. A cooling tower was used to reject the heat of condenser and absorber of the absorption chiller. A control strategy based on working hours was used to control pumps, fans of the air handling unit and cooling tower to save electricity. Among different available collector options, we selected an evacuated tube collector for this study because it is more efficient than flat plate collectors [26], and it can provide the required temperature to drive a single effect absorption chiller. In addition, the authors are not aware of a study that evaluates the performance of evacuated tube collectors with optimum annual and monthly tilt adjustments for the climate of Lahore, Pakistan. Figure 4 shows the TRNSYS model of the water-cooled VCC. Electrically driven water-cooled VCC produced chilled water as explained in Section 2.1, which was then passed to the air handling unit (AHU) and exchanged heat with air to meet the cooling load requirements of the building. A cooling tower is used to reject heat of the 
condenser. The characteristics of the main components are given in Tables 2 and 3. The mathematical descriptions of the main TRNSYS types (components) are described below.

Table 2. Evacuated tube collector and air handling unit specifications.

\begin{tabular}{cccccc}
\hline Parameter & \multicolumn{2}{c}{$\begin{array}{c}\text { Solar Collector } \\
\text { Unit Amount }\end{array}$} & Parameter & \multicolumn{2}{c}{$\begin{array}{c}\text { Air Handling Unit } \\
\text { Unit Amount }\end{array}$} \\
\hline Collector area & $\mathrm{m}^{2}$ & 2100 & Capacity & $\mathrm{CFM}$ & 87,272 \\
Optical efficiency & - & 0.73 & Water flow rate & $\mathrm{kg} / \mathrm{h}$ & 119,764 \\
$a_{1}$ & $\mathrm{~W} /\left(\mathrm{m}^{2} \mathrm{~K}\right)$ & 1.21 & Air flow rate & $\mathrm{kg} / \mathrm{h}$ & 249,657 \\
$a_{2}$ & $\mathrm{~W} /\left(\mathrm{m}^{2} \mathrm{~K}^{2}\right)$ & 0.0075 & & & \\
\hline
\end{tabular}

Table 3. The absorption chiller specifications.

\begin{tabular}{cccccc}
\hline Parameter & $\begin{array}{c}\text { ACS Chiller Temperature } \\
\text { Unit Amount }\end{array}$ & Parameter & $\begin{array}{c}\text { ACS Chiller Flow Rates } \\
\text { Unit Amount }\end{array}$ \\
\hline $\mathrm{HW}$ & ${ }^{\circ} \mathrm{C}$ & 110 & $\mathrm{HW}$ & $\mathrm{kg} / \mathrm{h}$ & 112,984 \\
$\mathrm{CHW}$ & ${ }^{\circ} \mathrm{C}$ & 6.67 & $\mathrm{CHW}$ & $\mathrm{kg} / \mathrm{h}$ & 119,764 \\
$\mathrm{CW}$ & ${ }^{\circ} \mathrm{C}$ & 29.44 & $\mathrm{CW}$ & $\mathrm{kg} / \mathrm{h}$ & 314,300 \\
\hline
\end{tabular}

\subsection{The Case Study Building}

In terms of sector-wise energy consumption of Pakistan, the industrial sector consumes the most $(37.7 \%)$ followed by the transport sector (32.2\%) and households sector $(22.2 \%)$ [2]. We selected a tyre manufacturing building hall located in Lahore, Pakistan as a case study. This is an actual existing building for which the building materials and dimensions are available: it is a single-floor building with total floor area of $3065.8 \mathrm{~m}^{2}$ and total volume of $30,369.8 \mathrm{~m}^{3}$. The building is exposed to the sun from all sides and has a glazing fraction (window to wall ratio) of $29.26 \%$ and $41.81 \%$ on the east and west sides, respectively. There are no windows on the south and north sides of the building, but 36 skylights (total area $86.96 \mathrm{~m}^{2}$ ) in the building roof provide daylight. To calculate building hourly cooling load over a one-year period, the SketchUp model was imported into TRNBuild and connected with the in-built typical meteorological year (TMY2) of Lahore. To model the thermal behavior of this building, we used a multi-zone building model (Type 56) which considers the variability of internal gains due to lights, equipment and occupants. The set point temperature $\left(26^{\circ} \mathrm{C}\right)$ and relative humidity $(50 \%)$ were considered as design conditions according to the comfortable range of temperature and relative humidity specified by ASHRAE (American Society of Heating, Refrigerating and Air-Conditioning Engineers) standards [27]. The building is an industrial building and its operating hours are from 09:00 to 18:00. The three-dimensional archetype of the selected building is shown in Figure 5 and thermal characteristics of the building envelop, gains and other design conditions considered for simulation are tabulated in Table 1.

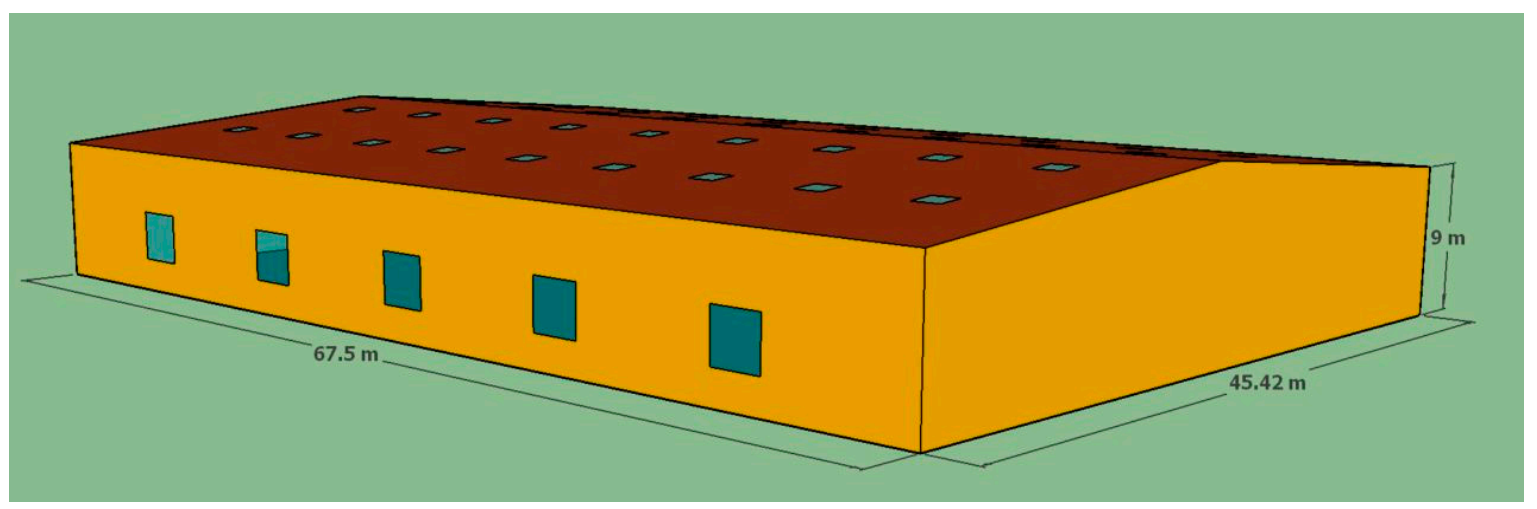

Figure 5. SketchUp model of the case study building. 


\subsection{Evacuated Tube Collector}

TRNSYS Type 71 was used to model this collector using a standard quadratic efficiency curve. The design parameters used in this type are representative of the Viessmann Vitosol 200 T SPE solar collector [28]. At steady state, we can write the energy balance of the solar collector as

$$
\mathrm{A}_{\mathrm{A}} \mathrm{G}=\mathrm{Q}_{\mathrm{u}}+\mathrm{Q}_{\text {losses }}
$$

$A_{A}$ represents collector aperture area, $G$ solar irradiance, $Q_{u}$ useful energy gain from collector. $Q_{\text {losses }}$ indicates energy losses due to optical properties of collector absorber surface $\left(Q_{\text {loss,opt }}\right)$ and by conduction, convection and radiation from collector surface as written in Equation (2).

$$
\mathrm{Q}_{\text {losses }}=\mathrm{Q}_{\text {loss,opt }}+\mathrm{Q}_{\text {loss, convective }}+\mathrm{Q}_{\text {loss, conductive }}+\mathrm{Q}_{\text {loss,radiative }}
$$

The rate of useful energy gain and efficiency of solar collector can be expressed by Equations (3) and (4), respectively [29].

$$
\mathrm{Q}_{\mathrm{u}}=\mathrm{mC}_{\mathrm{p}}(\text { Tout }- \text { Tin })
$$

where $m$ and $C_{p}$ represent the water mass flow rate and specific heat capacity of fluid, respectively. Tout and Tin represent the outlet and inlet temperatures of the collector.

$$
\eta_{\text {th }}=a_{0}-a_{1}\left(\frac{\Delta T}{G}\right)-a_{2} \frac{(\Delta T)^{2}}{G}
$$

where $a_{0}, a_{1}, a_{2}$ represents optical collector efficiency and first and second order heat loss coefficients, respectively. The parameters are given in Table 2 and were selected according to ASHRAE standards [30] rated by Solar Rating \& Certification Corporation (SRCC) from manufacturer catalogue. $\Delta \mathrm{T}$ indicates difference of average collector outlet temperature and ambient temperature.

\subsection{Hot Water Storage Tank}

In solar-driven ACS, an insulated water tank is usually used to store hot water for smooth operation of the absorption chiller and to operate the chiller in times of less or no solar irradiance. A large size tank can be expensive and is a source of heat loss, so size of tank and its aspect ratio should be chosen carefully [10]. We modelled the hot water vertical storage tank using TRNSYS Type 158 . The storage tank dissipates heat while interacting with the environment from the top, bottom and edges. The tank was divided into 10 iso-thermal temperature nodes for thermal stratification and the aspect ratio was chosen as 3.5 to minimize thermal losses as recommended by [31]. Heat can be transferred into and out of the storage tank depending on the temperature difference. Rate of change of temperature and heat loss from the top, edges and bottom of the storage for tank node $j$ is expressed by Equations (5)-(8).

$$
\frac{\mathrm{dT}_{\text {tan } k, j}}{\mathrm{dt}}=\left(\mathrm{Q}_{\mathrm{in}, \tan k, j}-\mathrm{Q}_{\text {out }, \tan k, j}\right) / C_{\text {tan } k, j}
$$

where $Q_{\text {in }}, Q_{\text {out }}$ represent heat transfer in and out of the tank and $C_{\text {tank }}$ shows thermal capacitance of the tank.

$$
\mathrm{Q}_{\text {loss,top }, \mathrm{j}}=\mathrm{A}_{\text {top }} \mathrm{U}_{\text {top }}\left(\mathrm{T}_{\text {tan } \mathrm{k}, \mathrm{j}}-\mathrm{T}_{\text {env,top }}\right)
$$

$\mathrm{Q}_{\text {loss,top }}$ shows amount of energy lost from top surface of tank, $\mathrm{A}$ is area, and $\mathrm{U}$ is heat transfer coefficient. $T_{\text {tank }}$ is tank temperature and $T_{\text {env }}$ is surrounding or environmental temperature.

$$
\begin{gathered}
\mathrm{Q}_{\text {loss,bottom }, \mathrm{j}}=\mathrm{A}_{\text {bottom }} \mathrm{U}_{\text {bottom }}\left(\mathrm{T}_{\text {tan } \mathrm{k}, \mathrm{j}}-\mathrm{T}_{\text {env }, \text { bottom }}\right) \\
\mathrm{Q}_{\text {loss }, \text { edge }, \mathrm{j}}=\mathrm{A}_{\text {edge }} \mathrm{U}_{\text {edge }}\left(\mathrm{T}_{\text {tan } \mathrm{k}, \mathrm{j}}-\mathrm{T}_{\text {env,edge }}\right)
\end{gathered}
$$




\subsection{Absorption Chiller}

To model a hot water operated absorption chiller, Type 107 (available in standard TRNSYS library) was chosen, which required a data file. The data file contains the fraction of design energy and cooling capacity of the machine, which are functions of HW, CW, CHW and part load conditions. Rated or design capacity is defined as the capacity of the chiller at design or rated conditions. It is also called nameplate capacity. Actual capacity is capacity of chiller at current conditions of hot water, chilled water and cooling water. The main design parameters of this chiller are given in Table 3.

The fraction of design load (ratio of current load w.r.t. rated capacity) at which the machine is required to operate can be calculated using the following equations.

$$
\mathrm{f}_{\text {Design Load }}=\frac{\mathrm{Q}_{\text {removed }}}{\text { Cap }_{\text {Rated }}}
$$

where $\mathrm{Q}_{\text {removed }}$ is the amount of energy removed from the CHW stream to achieve the desired set

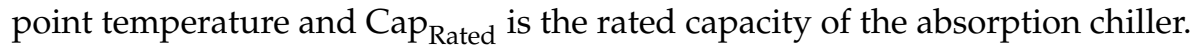

The actual capacity of the machine at any time step is calculated by using Equation (10).

$$
\text { Capacity }=\mathrm{f}_{\text {FullLoadCapacity }} * \mathrm{f}_{\text {NominalCapacity }} * \text { Cap } \text { Rated }
$$

where, $\mathrm{f}_{\text {FullLoadCapacity }}$ is ratio of load divided by actual capacity and $\mathrm{f}_{\text {NominalCapacity }}$ capacity at current conditions to capacity at design conditions.

The model used the following relations to find the outlet temperature of the hot water $\left(\mathrm{T}_{\mathrm{hw}, \mathrm{out}}\right)$, chilled water $\left(\mathrm{T}_{\text {chw,out }}\right)$ and cooled water $\left(\mathrm{T}_{\mathrm{cw}, \text { out }}\right)$ streams,

$$
\begin{gathered}
\mathrm{T}_{\mathrm{hw}, \text { out }}=\mathrm{T}_{\mathrm{hw}, \text { in }}-\frac{\mathrm{Q}_{\mathrm{hw}}}{\mathrm{m}_{\mathrm{hw}} \mathrm{C}_{\mathrm{phw}}} \\
\mathrm{T}_{\mathrm{chw}, \text { out }}=\mathrm{T}_{\mathrm{chw}, \text { in }}-\frac{\mathrm{Q}_{\mathrm{chw}}}{\mathrm{m}_{\mathrm{hw}} \mathrm{C}_{\mathrm{pchw}}} \\
\mathrm{T}_{\mathrm{cw}, \text { out }}=\mathrm{T}_{\mathrm{cw}, \text { in }}+\frac{\mathrm{Q}_{\mathrm{cw}}}{\mathrm{m}_{\mathrm{cw}} \mathrm{C}_{\mathrm{pcw}}}
\end{gathered}
$$

where $\mathrm{Q}_{\mathrm{hw}^{\prime}}, \mathrm{Q}_{\mathrm{cw}}$ and $\mathrm{Q}_{\mathrm{chw}}$ are HW, CW and CHW energy streams, respectively. The parameters $\mathrm{m}$ and $C_{p}$ give the mass flow rate and specific heat capacity of water in the loop indicated by the subscript. The amount of energy dissipated from the cooling water can be written by Equation (14),

$$
\mathrm{Q}_{\mathrm{cw}}=\mathrm{Q}_{\mathrm{chw}}+\mathrm{Q}_{\mathrm{hw}}+\mathrm{P}_{\mathrm{el}, \mathrm{aux}}
$$

where $\mathrm{P}_{\text {el,aux }}$ accounts for the energy consumed by solution pumps and controllers.

The Coefficient of Performance (COP) of the chiller is defined as

$$
\mathrm{COP}=\frac{\mathrm{Q}_{\mathrm{chw}}}{\mathrm{Q}_{\mathrm{aux}}+\mathrm{Q}_{\mathrm{hw}}}
$$

Solar fraction (SF) is the fraction of load covered by solar energy. It can be expressed as

$$
\mathrm{SF}=\frac{\mathrm{Q}_{\text {solar }}}{\mathrm{Q}_{\text {solar }}+\mathrm{Q}_{\mathrm{aux}}}
$$

Performance maps for a single-stage absorption chiller are shown in Figure 6a,b. Figure 6a shows the fraction of nominal capacity as a function of cooling water inlet temperature for different chilled water temperatures, which illustrate that cooling capacity increased by reducing the cooling water temperature and setting chilled water temperature to a higher value. Figure $6 \mathrm{~b}$ illustrates part load 
performance of the machine at different cooling water temperatures and it shows that the machine requires more energy at higher part load ratios. For a fixed part load ratio, the machine efficiency can be improved by reducing cooling water temperature.

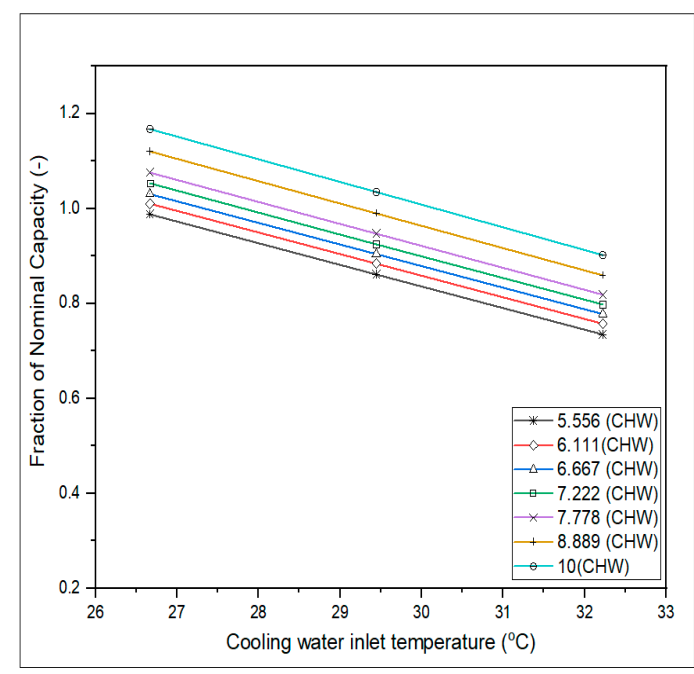

(a)

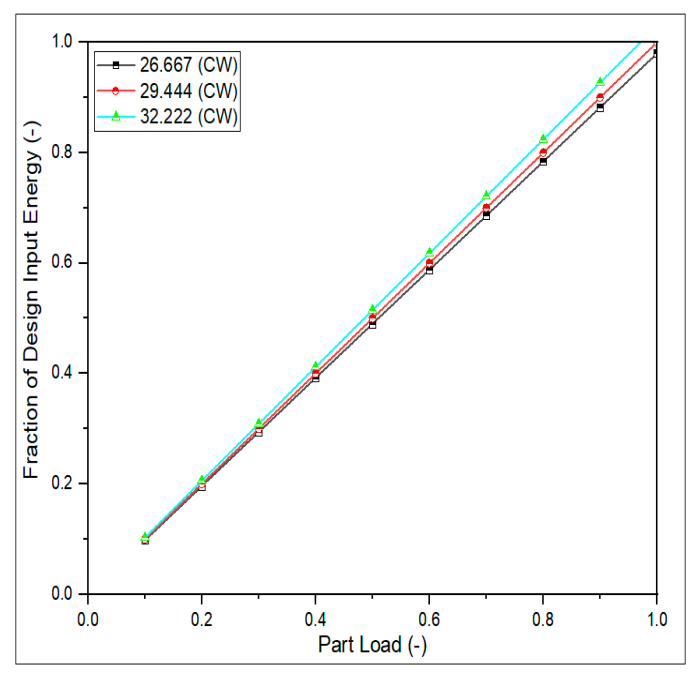

(b)

Figure 6. (a) Fraction of nominal capacity with varying cooling water inlet temperature at different chilled water temperatures for absorption cooling system (ACS); (b) fraction of design input energy at different part load ratio for ACS.

\subsection{Vapour Compression Chiller}

To compare the conventional cooling system with the solar-driven vapour absorption cycle, a water-cooled VCC chiller was modelled by TRNSYS Type 666.

The chiller load and part load ratio (PLR) for each time step are calculated as

$$
\begin{gathered}
\mathrm{Q}_{\text {load }}=\mathrm{m}_{\text {chw }} * \mathrm{C}_{\mathrm{p}}\left(\mathrm{T}_{\text {chw,in }}-\mathrm{T}_{\text {chw,set }}\right) \\
\text { PLR }=\frac{\mathrm{Q}_{\text {load }}}{\text { Capacity }}
\end{gathered}
$$

\subsection{Cooling Tower}

A cooling tower which is modelled with TRNSYS Type 510 is used to remove heat from the condenser and absorber of the ACS. A variable flow rate fan was used to achieve the desired fluid temperature with control signals. The performance map (see Figure $6 \mathrm{a}, \mathrm{b}$ ) shows that cooling water temperature (CW) strongly influences ACS performance. Most of the time, this low-grade heat is dissipated to the environment but it could be used for some industrial processes as well [32]. The most commonly used heat rejection device is a cooling tower, which achieves cooling through the evaporation of water. One of the limitations of an air cooled cooling tower is that the lowest temperature that can be achieved is the wet bulb temperature of the air [10].

\subsection{Pumps}

Pumps are used to circulate fluid in the different loops, i.e., collector, HW, CW and CHW loops. These pumps consume energy to perform mechanical work and electricity is the most common source to operate these pumps. 
The pump shaft power $\left(\mathrm{P}_{\text {shaft }}\right)$ and amount of energy transferred to fluid stream $\left(\mathrm{Q}_{\text {fluid }}\right)$ is calculated by Equations (19) and (20), respectively.

$$
P_{\text {shaft }}=P * \eta_{m}
$$

where $P$ is power drawn by the pump in the current time step of the simulation and $\eta_{m}$ is the motor efficiency.

$$
Q_{\text {fluid }}=P_{\text {shaft }}\left(1-\eta_{p}\right)+\left(P-P_{\text {shaft }}\right) f_{\text {motorloss }}
$$

where $\eta_{p}$ represents pump efficiency and $f_{\text {motorloss }}$ shows fraction of pump motor efficiencies that contribute to temperature rise in the fluid stream passing through the pump.

\subsection{Pipes}

TRNSYS Type 31 was used to model the thermal behavior of fluid flow in pipes. The equal friction method was used to determine the size of pipes in each loop based on flow rate.

\subsection{System Performance Indices}

The performance of the chillers was evaluated based on energetic, economic and environmental (3E) performance metrics. Total primary energy consumption, levelized annual capital investment taking into account both initial investment and running cost, and carbon footprint indices were used to compare both systems. Annualized cost of both system were calculated considering cost function tabulated in Table 4 and in order to carry out energetic assessment, total primary energy consumption of the system was calculated. For the operation of solar-driven ACS, it utilizes electricity (to drive different pumps and fans) and natural gas (used in an auxiliary boiler to raise the temperature of hot water in the case of less solar irradiance), but water-cooled VCC is electrically driven and only utilizes electricity (to drive the compressor, different pumps and fans). Therefore, the primary energy consumption for a solar-driven ACS system ( $\mathrm{PEC}_{\mathrm{ACS}}$ ) and water-cooled VCC system ( $\mathrm{PEC}_{\mathrm{VCC}}$ ) can be expressed by Equations (21) and (22), respectively.

$$
\begin{gathered}
\mathrm{PEC}_{\mathrm{ACS}}=\left(\mathrm{PEF}_{\mathrm{E}} \times \mathrm{E}_{\mathrm{E}}+\mathrm{PEF}_{\mathrm{NG}} \times \mathrm{E}_{\mathrm{NG}}\right) \\
\mathrm{PEC}_{\mathrm{VCC}}=\left(\mathrm{PEF}_{\mathrm{E}} \times \mathrm{E}_{\mathrm{E}}\right)
\end{gathered}
$$

where $\mathrm{E}_{\mathrm{E}}$ and $\mathrm{E}_{\mathrm{NG}}$ are total annual consumption of electricity and natural gas, respectively. $\mathrm{PEF}_{\mathrm{E}}$ and $\mathrm{PEF}_{\mathrm{NG}}$ represents primary energy factor for electricity and natural gas, respectively. The values of these factor are given in Table 5. The primary energy saving (PES) in the case of using solar-driven ACS can be expressed as:

$$
\mathrm{PES}=\left(\mathrm{PEC}_{\mathrm{VCC}}-\mathrm{PEC}_{\mathrm{ACS}}\right)
$$

Table 4. Capital cost functions of main components obtained from market analysis (Pakistani Rupees) [33].

\begin{tabular}{cccc}
\hline Parameter & Cost Function & Parameter & Cost Function \\
\hline ETC collector & 25,000 per m ${ }^{2}$ & Hot water storage tank & 40,000 per $\mathrm{m}^{3}$ \\
Auxiliary boiler & 110,000 per $\mathrm{kW}$ & Single-effect absorption chiller & 31,250 per $\mathrm{kW}^{-}$ \\
Vapour compression chiller & 25,568 per kW & Cooling tower & 2840 per $\mathrm{kW}$ \\
Pump & 6000 per $\mathrm{kW}$ & & \\
\hline
\end{tabular}


To calculate annualized capital cost of both systems, the cost functions tabulated in Table 4 were considered. Total capital investment is the sum of cost of individual components and installation cost. Levelized capital cost $\left(\mathrm{CI}_{\mathrm{L}}\right)$ can be calculated as

$$
\mathrm{CI}_{\mathrm{L}}=\left(\sum \mathrm{Z}_{\mathrm{k}}+\mathrm{C}_{\mathrm{INSTL}}\right) * \mathrm{CRF}
$$

where $\sum Z_{\mathrm{k}}$ represents sum of capital cost of all components and $C_{\text {INSTL }}$ shows installation cost.

To take into account the project lifetime (n) and interest rate (i), we considered capital recovery factor (CRF), which can be expressed as:

$$
\mathrm{CRF}=\frac{\mathrm{i}(1+\mathrm{i})^{\mathrm{n}}}{(1+\mathrm{i})^{\mathrm{n}}-1}
$$

The running cost in the case of the conventional VCC is given by the electricity required to run pumps and the compressor, while for the thermal driven ACS, electricity or a combination of electricity and natural gas is used. Electricity is used to drive pumps and fans while natural gas or electricity (electric resistance heater) is used to provide auxiliary energy to the hot water loop to achieve the required driving temperature for the absorption chiller in times of insufficient solar irradiance.

Annual cost of electricity and natural gas consumption can be calculated by using Equations (26) and (27).

$$
\begin{gathered}
\mathrm{FC}_{\mathrm{E}}=\mathrm{E}_{\mathrm{E}} \times \mathrm{c}_{\mathrm{E}} \\
\mathrm{FC}_{\mathrm{NG}}=\mathrm{E}_{\mathrm{NG}} \times \mathrm{c}_{\mathrm{NG}}
\end{gathered}
$$

where $\mathrm{FC}_{\mathrm{E}}$ and $\mathrm{FC}_{\mathrm{NG}}$ are annual cost of electricity and natural gas consumption, while $\mathrm{E}_{\mathrm{E}}, \mathrm{E}_{\mathrm{NG}}$, $\mathrm{C}_{\mathrm{E}}$ and $\mathrm{c}_{\mathrm{NG}}$ are total electricity consumed, total natural gas consumed, unit cost of electricity and unit cost of natural gas, respectively. The total annual $\mathrm{CO}_{2}$ emissions (CDE) are the sum of emissions produced from electricity $\left(\mathrm{CDE}_{\mathrm{E}}\right)$ and emissions from burning natural gas $\left(\mathrm{CDE}_{\mathrm{NG}}\right)$ in the auxiliary boiler. These are given by

$$
\begin{gathered}
\mathrm{CDE}=\mathrm{CDE}_{\mathrm{E}}+\mathrm{CDE}_{\mathrm{NG}} \\
\mathrm{CDE}_{\mathrm{E}}=\mathrm{E}_{\mathrm{E}} * \mathrm{EF}_{\mathrm{CO}_{2}, \mathrm{E}} \\
\mathrm{CDE}_{\mathrm{NG}}=\mathrm{E}_{\mathrm{NG}} * \mathrm{EF}_{\mathrm{CO}_{2}, \mathrm{NG}}
\end{gathered}
$$

where $\mathrm{E}_{\mathrm{E}}$ and $\mathrm{E}_{\mathrm{NG}}$ are total electricity and natural gas consumed. $\mathrm{EF}_{\mathrm{CO}_{2}, \mathrm{E}}$ and $\mathrm{EF}_{\mathrm{CO}_{2}, \mathrm{NG}}$ are $\mathrm{CO}_{2}$ emission factors for grid electricity and natural gas, which are listed in Table 5.

\subsection{Model Validation}

TRNSYS, which was developed by the University of Wisconsin, validates each type (component) before providing it to the TRNSYS users [34], which indicates that all components available in TRNSYS are themselves validated. However, it is still important to check that the types and their parameters are correctly implemented in the model. Typically, building energy modelling tools are benchmarked using a standard called ASHRAE 140 [35] and the building modelling tool used for this study (TRNSYS) has been through that test protocol a number of times.

To validate the building model, we compared the peak calculated cooling load $(712 \mathrm{~kW})$ with installed cooling equipment capacity $(774.4 \mathrm{~kW})$ which shows the correct implementation of the building model. The installed cooling capacity is slightly higher (a general practice) to incorporate future needs (more installation of machinery inside the building, which will result in higher internal gains) and global warming issues (increase in outdoor temperature). In this study, the VIESMANN Vitsol 200 T collectors (SRCC certified) were selected for the ACS simulation model. Solar thermal collectors are tested according to Solar Rating and Certificate Corporation (SRCC) standards. There are different categories of tests like high temperature resistance (to access that a collector can withstand 
stagnation under high irradiance level), thermal performance test (to determine how energy can be gained from a collector at different temperatures and irradiance), exposure and rain test, internal and external thermal shock test, and mechanical load and impact resistance test. Thermal efficiency of the collector at different temperatures (Figure 7a) and optical efficiency, and first and second order heat loss coefficients of this collector (tabulated in Table 2) were extracted from the manufacturer's catalogue [28]. Then, to verify the correct implementation of this collector in TRNSYS, it was tested against the SRCC thermal performance test under similar conditions. Results indicate that a maximum discrepancy of less than $2 \%$ between the simulated and reported efficiency was found, which indicates acceptable accuracy of the collector's model in TRNSYS as well as correct implementation in the model. The absorption chiller was modelled by the characteristic equation method $[36,37]$ which utilizes two correlations to determine cooling capacity and design heat input. This cooling capacity and fraction of design energy input further depend on cooling water temperature, chilled water temperature, hot water temperature and part load performance (see Figure 6). In this study, data provided by the manufacturer [38] was compared with the performance data file of TRNSYS Type 107 and discrepancy was found to be less than $5 \%$, which shows acceptable accuracy of the simulation models.

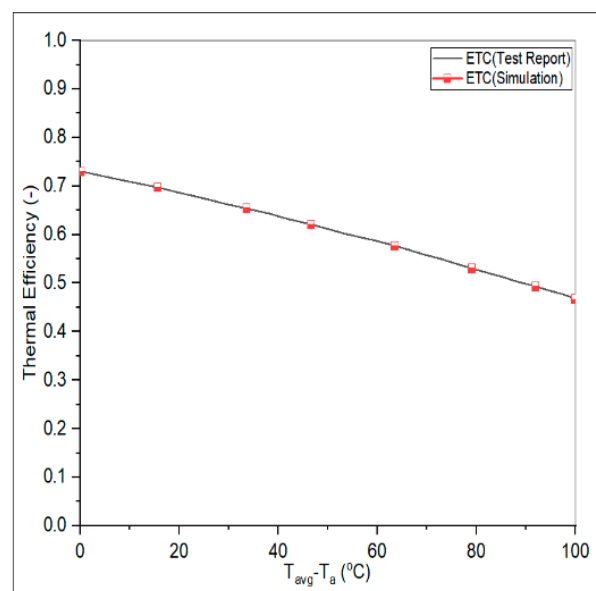

(a)

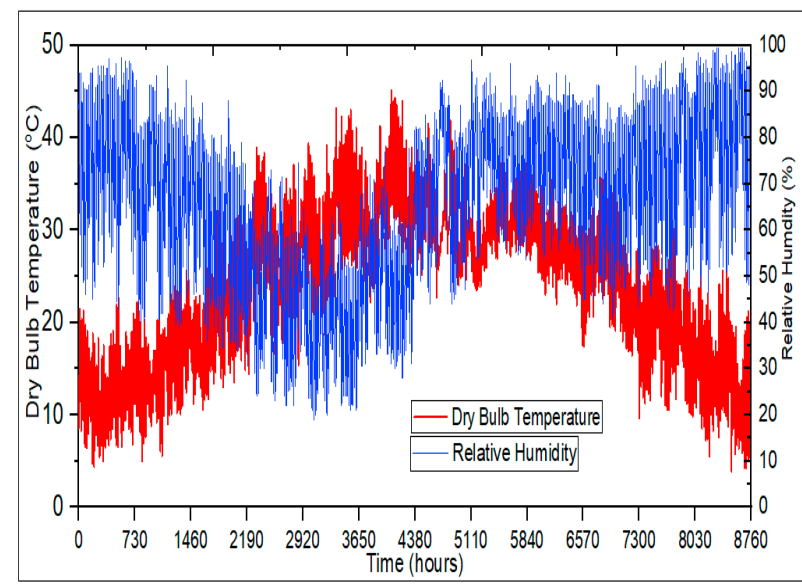

(b)

Figure 7. (a) Comparison of collector efficiency curve (simulation vs. experimental data reported by the collector's manufacturer at $\left.\mathrm{G}=1000 \mathrm{~W} / \mathrm{m}^{2}\right)$; (b) daily temperature and humidity variation for Lahore, Pakistan.

Table 5. Parameters considered for energetic, economic and environmental (3E) analyses in this study.

\begin{tabular}{|c|c|c|c|c|c|}
\hline Parameter & Unit & Amount & Parameter & Unit & Amount \\
\hline $\begin{array}{c}\text { Interest rate or } \\
\text { discount rate (i) [39] }\end{array}$ & $\%$ & 13.25 & Installation cost of $\mathrm{ABS}$ & $\%$ of CI & 150 \\
\hline $\begin{array}{c}\text { Average electricity } \\
\text { price [40] }\end{array}$ & Rs./kWh & 20 & Installation cost of VCS & $\%$ of $C I$ & 130 \\
\hline $\begin{array}{l}\text { Average natural gas } \\
\text { price }[41]\end{array}$ & Rs. $/ \mathrm{m}^{3} / \mathrm{h}$ & 15 & $\begin{array}{l}\mathrm{CO}_{2} \text { emission factor for } \\
\text { electricity [42] }\end{array}$ & $\begin{array}{l}\text { kg per } \\
\text { MWh }\end{array}$ & 566 \\
\hline Lifetime of solar plant & Years & 23 & $\begin{array}{c}\mathrm{CO}_{2} \text { emission factor for } \\
\text { natural gas [42] }\end{array}$ & $\begin{array}{l}\text { kg per } \\
\text { MWh }\end{array}$ & 202 \\
\hline $\begin{array}{l}\text { Primary energy factor } \\
\text { for natural gas [43] }\end{array}$ & $\mathrm{kWh}_{\mathrm{PE}} / \mathrm{kWh}_{\mathrm{NG}}$ & 1.22 & $\begin{array}{c}\text { Primary energy factor for } \\
\text { electricity [43] }\end{array}$ & $\mathrm{kWh}_{\mathrm{PE}} / \mathrm{kWh}$ & 3.05 \\
\hline
\end{tabular}

\section{Results and Discussion}

This section presents the TRNSYS simulation results. First, the weather data, monthly cooling load and breakdown analysis of cooling load results are discussed. Then water-cooled compression 
chiller and solar-driven absorption chiller performance results are presented, and in the last section parametric results are presented.

\subsection{Weather Data}

Figure $7 \mathrm{~b}$ shows daily variation in temperature and relative humidity for the case study building located in Lahore, Pakistan, which has a warm and humid climate. Ambient temperature of Lahore varies from $3{ }^{\circ} \mathrm{C}$ in winter to $45^{\circ} \mathrm{C}$ in peak summer season and relative humidity remains around $50 \%$ at the start of summer and reaches up to $70 \%-80 \%$ in the rainy season (July-September). The summer season of Lahore lasts from March to the mid of November. The natural atmospheric temperature for climate of Lahore remains above the ASHRAE defined comfort zone for most of the year. Therefore, some type of HVAC equipment is required to displace room heat gains to maintain comfortable indoor temperatures.

\subsection{Cooling Load}

The first step in sizing any HVAC system is to determine the cooling load, which is the amount of energy required to offset heat gains so that the room temperature stays within the comfort zone. The designed conditions, such as temperature and relative humidity, used for calculation of cooling load are listed in Table 1. Building zone air receives heat from internal and external gains. External heat gains are given by the energy that enters the building through its envelop, such as walls, windows, doors, roof and floor. Internal gains are due to thermal energy released by lights, equipment and occupants. Gains that increase the temperature of air are called sensible gains, while gains that add moisture to the space are named latent heat gains.

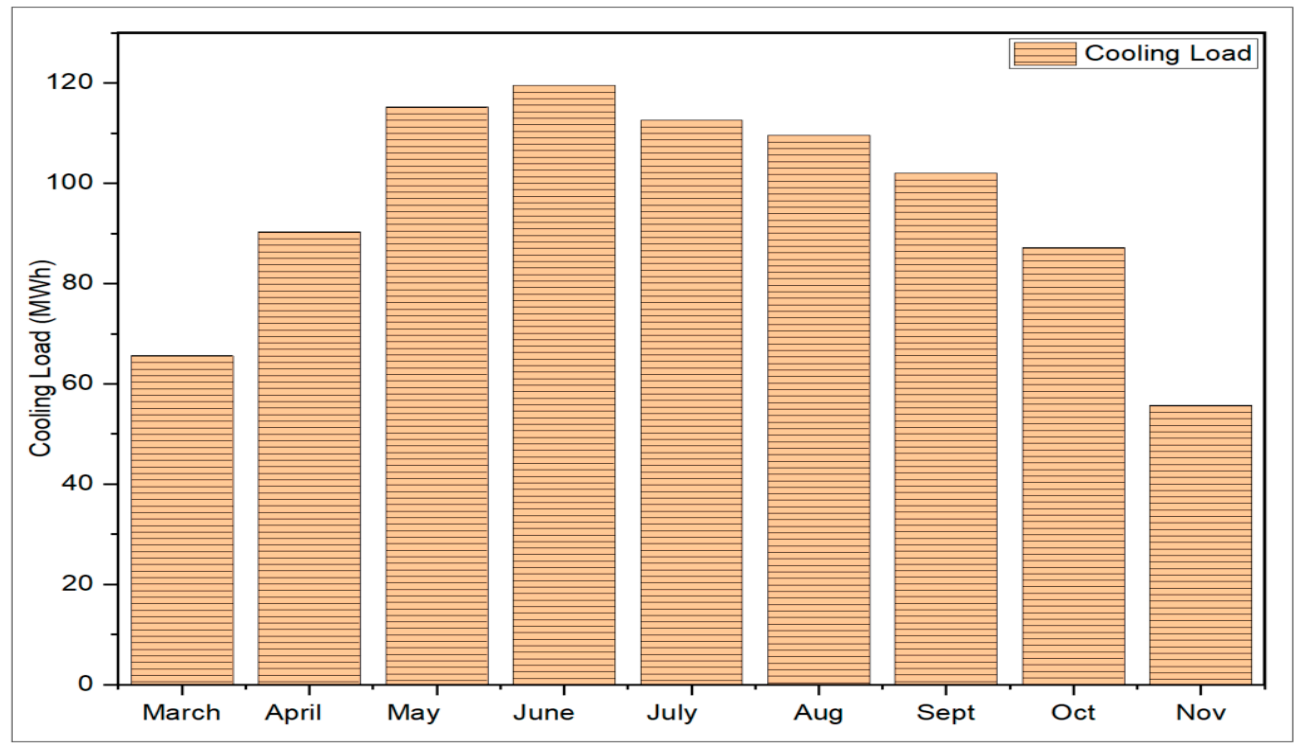

Figure 8. Monthly building cooling load.

In the developed model, both sensible and latent heat gains and variability of these heat gains at different times of the day were considered. The share of internal and external gains in the total cooling load was calculated as $47 \%$ and $53 \%$, respectively. The share of high internal gains is due to equipment load (machinery) and number of occupants working inside the building. The room cooling load is the amount of energy required to displace all internal and external heat gains to achieve design set point temperature and relative humidity. The largest heat gains are from building envelop (walls, roof and floor) followed by heat released by building's equipment. The other major gain is heat from infiltration, i.e., influx of outside air through windows or door usage. The amount of heat gains from people and windows through conduction were calculated as $2 \%$ and $6 \%$, respectively. The lowest heat gains $(<1 \%)$ 
are from lights because the selected building operates only during the daytime ( 9 a.m. to 6 p.m.) and to utilize solar irradiance for day lighting, sky lights of $87 \mathrm{~m}^{2}$ were used. It is noted from the simulation results that maximal amount of solar irradiance was absorbed by the building roof and large number of sky lights (which on the one side provide daylight but on the other hand this irradiance becomes a heat load). It was also noted that solar irradiance from the east and west walls were higher compared to the north and south side of the building. Therefore, some retrofitting techniques (insulation) can be applied to the roof and east and west walls to reduce the external heat gains to the building, thereby reducing overall cooling load. The bar chart (Figure 8) shows the monthly cooling load variation over the summer season. In the months of March and November, outside air temperature lies in the range of $20^{\circ} \mathrm{C}$ to $30^{\circ} \mathrm{C}$ so there is less need of cooling in these months. The maximum cooling load demand is in the month of May, June and July when ambient temperature normally goes above $40^{\circ} \mathrm{C}$.

\subsection{Water-Cooled Vapour Compression Chiller Results}

This section presents the performance of the VCC chiller to fulfil the peak cooling load of $712 \mathrm{~kW}$. The TRNSYS model of the water-cooled VCC chiller is shown in Figure 4.

The simulation of the water-cooled VCC model was carried out over a summer season with a time step of $1 \mathrm{~h}$. Since the peak cooling load requirements are in June, Figure 9a illustrates the variation of temperature (ambient and zone) and solar flux over two sunny and one cloudy day in June. Looking at ambient temperature and solar flux of peak hours of the sunny days shows that ambient temperature goes above $40{ }^{\circ} \mathrm{C}$ with a corresponding solar flux of around $1000 \mathrm{~W} / \mathrm{m}^{2}$. The operating hours for the building were only from 9 a.m. to 6 p.m. and the thermostat was set at $26^{\circ} \mathrm{C}$. The building zone temperature (Tair_Hall) is maintained by water-cooled VCC at the required design set point temperature by offsetting all external and internal gains. The monthly energy consumption of the compressor to fulfil the cooling load and the monthly heat rejection from the condenser are shown in Figure $9 \mathrm{~b}$. It is interesting to note that compressor monthly energy consumption in the months of July and August is higher compared to June. This is due to the effect that the VCC system performs poorly in a humid environment. It can be seen from Figure $7 \mathrm{~b}$ that July and August are humid months in Lahore, Pakistan, which results in high latent load and lower performance of the VCC system.

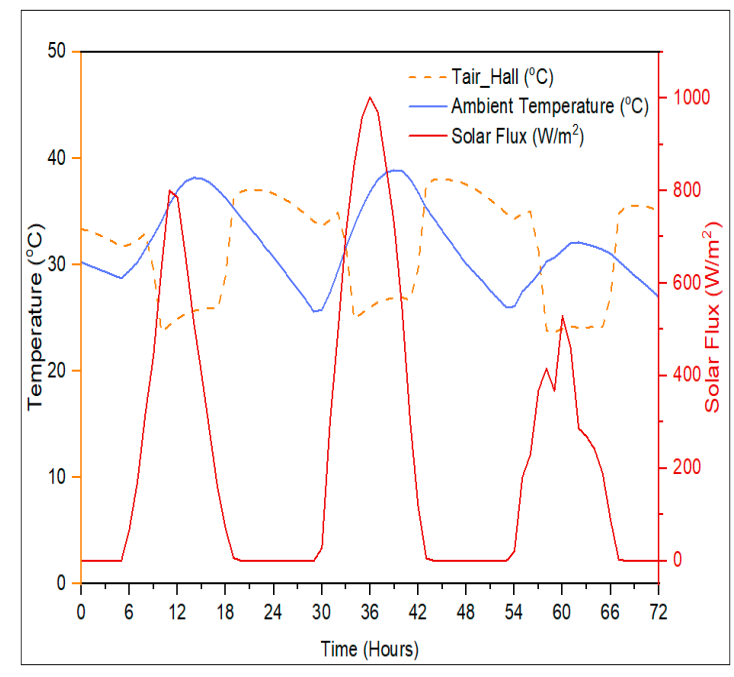

(a)

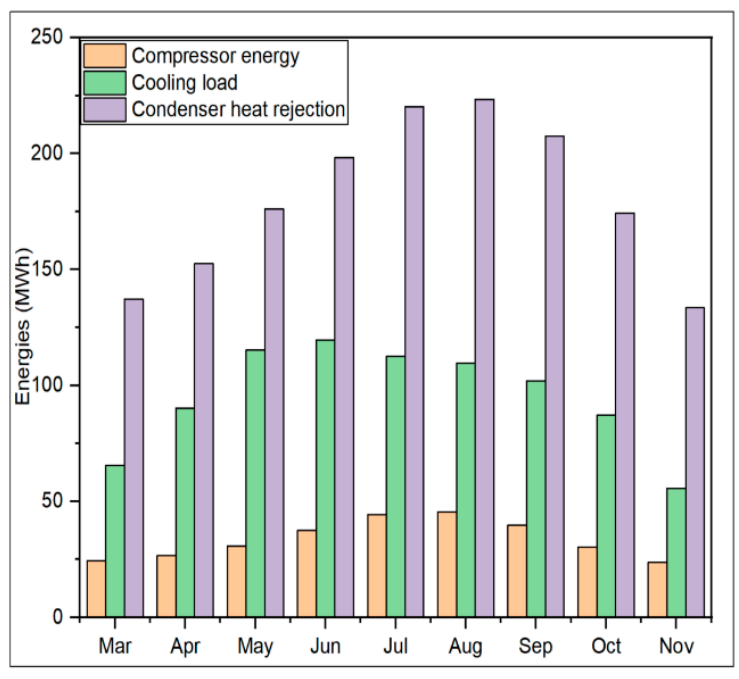

(b)

Figure 9. (a) Simulation results of water-cooled vapour compression cycle (VCC) chiller for three days (3rd to 5th June of the typical metrological year). (b) Water-cooled VCC chiller monthly results. 


\subsection{Solar-Driven Vapour Absorption Chiller Results}

This section presents the performance (temperature and energies of different loops) of hot water solar operated absorption chillers. Figure 10a shows the temperature and energies of hot water, cooling water and chilled water streams. The chiller starts working according to the defined scheduled (9 a.m.) and operates continuously for $9 \mathrm{~h}$. During the chiller's operation, solar collectors are used to harness solar energy in the form of hot water.

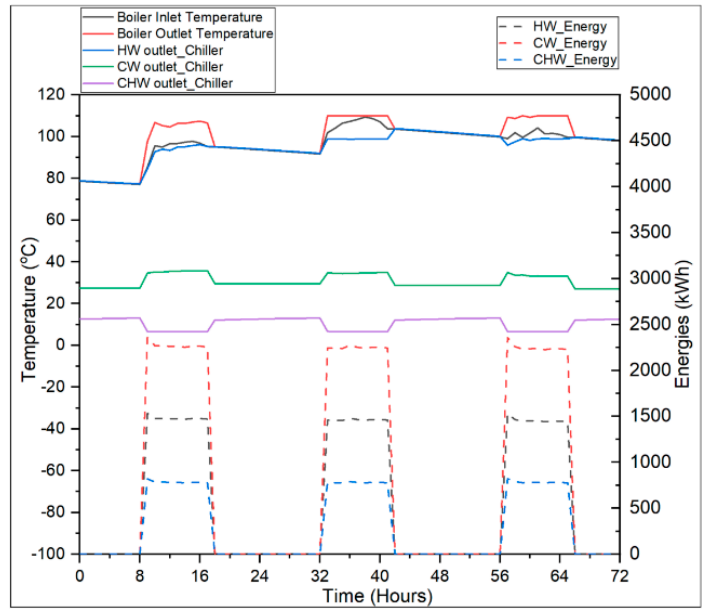

(a)

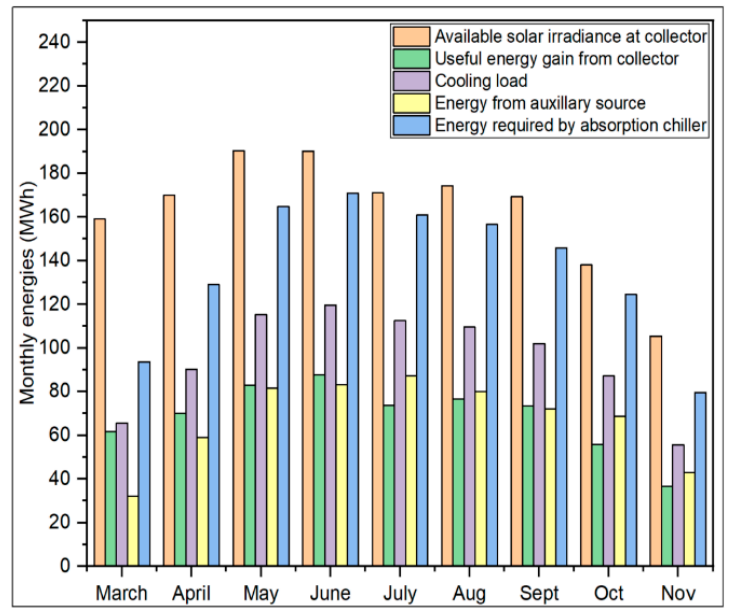

(b)

Figure 10. (a) Chiller outlet temperature and energies of hot water, cooling water and chilled water loop for three days from 03.06. to 05.06. (b) evacuated tube collector (ETC) + absorption chiller results at collector area $\left(\mathrm{A}_{\mathrm{c}}\right)=1000 \mathrm{~m}^{2}$.

This HW is stored in a thermally stratified vertical configuration tank. The pump of the hot water loop circulates this HW from the tank to the boiler. To raise the temperature of hot water in the case of insufficient solar irradiance, an auxiliary boiler is installed in series. One benefit of solar-driven chillers is the coincidence of the higher solar flux with the peak cooling load. In this model, chilled water outlet temperature from chiller was set to $6.7^{\circ} \mathrm{C}$ during operating hours as evident from Figure $10 \mathrm{a}$, and the cooling water outlet temperature rose to $34.9^{\circ} \mathrm{C}$. The cooling tower in this model was designed for $5.5^{\circ} \mathrm{C}$ temperature difference. The right $y$-axis of Figure 10 a shows the amount of energy required in different fluid streams. The amount of energy rejected by the cooling tower is the sum of energy entered to the generator and chilled water energy. Cooling water dissipates heat from the condenser and absorber of the ACS. Monthly yield of solar assisted absorption chiller is shown in Figure 10b, which represents monthly energy data, i.e., energy available at solar collector, useful energy gain from collector, monthly auxiliary energy requirement, monthly cooling load and amount of monthly energy absorption chiller needed to produce the required cooling effect. The efficiency of the solar collector can be calculated by dividing the useful energy gain from the collector by the total solar irradiance available at the collector according to Equation (4). In this simulation, we got the maximum monthly collector efficiency in the month of May and June, which is in line with maximum cooling load demand. As the solar irradiance and ambient temperature varies throughout the year, so does the collector efficiency as it depends on solar irradiance and difference of average fluid and ambient temperature. To produce the cooling effect and to offset heat gains of the building zone to maintain design temperature, the absorption chiller needed heat energy that comes from two sources, i.e., energy from solar collector and energy from auxiliary source. The COP of the absorption chiller can be calculated by dividing the provided cooling load by the total amount of energy the absorption chiller needs to produce this cooling effect according to Equation (15). We found a maximal COP of 0.68 , which agrees with the manufacturer data [38]. It is interesting to note that peak cooling load 
requirements in the months of May, June and July are in line with maximal solar irradiance available at the solar collector, thereby reducing the energy consumption requirement from the auxiliary source.

\subsection{Energetic, Economic and Environmental (3E) Results}

This section discusses comparative performance of a water-cooled vapour compression system with a solar-driven vapour absorption cooling system on energetic, economic and environmental indices as tabulated in Table 6. Energetic analysis compares the annual energy consumed by water-cooled VCC and solar-driven ACS to meet the cooling demand. Economic analysis takes into account both the capital investment and running costs. Total energy $\mathrm{CO}_{2}$ emissions factor for electricity and natural gas were considered to carry out the environmental analysis of both systems. Primary energy consumption of both systems was calculated using the TRNSYS model using Equations (20) and (21), and results show that the solar-driven cooling system utilized $5.74 \times 10^{5} \mathrm{kWh}$ of annual primary energy. On the other hand, annual primary energy consumption of water-cooled VCC systems was calculated as $2.23 \times 10^{6}$, which is 3.88 times higher than the solar-driven cooling system. The calculation of primary energy saving shows that $1.65 \times 10^{6} \mathrm{kWh}$ of primary energy can be saved annually in the case of using the solar-driven ACS system to meet the cooling demand.

Table 6. 3E results of VCC and ACS system.

\begin{tabular}{|c|c|c|c|}
\hline Sr.No & Parameter & VCC System & ACS System \\
\hline 1 & $\begin{array}{c}\text { Annual primary energy } \\
\text { consumption }(\mathrm{kWh})\end{array}$ & $2.23 \times 10^{6}$ & $5.74 \times 10^{5}$ \\
\hline 2 & $\begin{array}{c}\text { Annualized capital } \\
\text { investment cost (Rs.) }\end{array}$ & $1.07 \times 10^{7}$ & $3.31 \times 10^{7}$ \\
\hline 3 & Monthly running cost (Rs.) & $1,612,186$ & 393,269 \\
\hline 4 & Annual $\mathrm{CO}_{2}$ emissions (tons) & 346.78 & 108.58 \\
\hline
\end{tabular}

The calculation of annualized capital investment results shows that the solar-driven ACS cooling system is 3.1 times more expensive than the water-cooled VCC system based on the current discount rate of Pakistan in 2020. It was found that the annualized capital investment cost of solar-driven ACS system is $3.31 \times 10^{7}$ Pakistani rupees (with collector area of $2100 \mathrm{~m}^{2}$ ), while cost of the water-cooled VCC system was $1.07 \times 10^{7}$ Pakistani rupees. For the calculation of annualized cost, only discount rate was considered for initial investment cost of components. Fuel escalation rate of electricity and natural gas was not taken into account while calculating annualized costs of both systems. The high cost of the solar-driven ACS system is due to high discount rates. Further sensitivity analysis was performed by considering a subsidized discount factor of $10 \%$ and $8 \%$ for solar-driven ACS systems only. Results show that with $10 \%$ and $8 \%$ subsidized discount factors, the solar-driven cooling system is 2.4 and two times more expensive than a conventional VCC system for the climate of Pakistan. To calculate running cost of both systems, total annual energy consumption was calculated. It was calculated that monthly bills in the case of solar-driven ACS (with collector area $2100 \mathrm{~m}^{2}$ ) will be 393,269 Pakistan rupees, while for water-cooled VCC, this will cost 1,612,186 Pakistani rupees, which is 4.1-times higher than for the solar system.

Finally, the environmental impact of both systems was studied and the results show that annual $\mathrm{CO}_{2}$ emissions in the case of using solar-driven ACS (with collector area of $2100 \mathrm{~m}^{2}$ ) for the selected building will be 3.19-times lower than water-cooled VCC. The total emissions were calculated using Equation (28) considering emission factors for electricity and natural gas and annual $\mathrm{CO}_{2}$ emissions from solar-driven ACS and water-cooled VCC were calculated as 108.58 and 346.78 tons, respectively.

\subsection{Parametric Study}

In this section, a detailed parametric study is performed to investigate the effect of the critical parameters like solar field size, storage tank volume, flow rate in solar collector loop, solar tilt 
and azimuthal angle with annual and monthly optimized adjustment on the performance of the solar-driven ACS.

Figure 11a shows the relation of annual useful energy gain and annual auxiliary energy requirement to operate the absorption chiller by varying the collector area from $500 \mathrm{~m}^{2}$ to $3000 \mathrm{~m}^{2}$. This shows that annual useful energy gain from the solar field increases by increasing the solar field size and the auxiliary energy requirement decreases. By increasing the solar field, the solar fraction increases almost linearly up to an optimum collector area which depends on the cooling load. After this optimum point, solar fraction does not increase linearly, and it is not beneficial to increase the collector area further. It is evident from Figure 11a that solar fraction is not increasing significantly after the $2100 \mathrm{~m}^{2}$ solar collector area. By increasing the collector area from $2100 \mathrm{~m}^{2}$ to $3000 \mathrm{~m}^{2}$, solar fraction increased only by $8 \%$. So, rather than increasing the solar fraction to higher values, it is better to use an auxiliary heat source to achieve absorption chiller driving temperatures. The effect of variation of storage tank size on solar fraction was also investigated and it was found that storage tank volume is less sensitive to solar fraction. The solar fraction does increase with an increase in solar field area, but it does not show any significant increment with the storage tank volume because the system operates only during the day and no energy is needed for nighttime operation. The parametric study results indicate that a storage tank volume of $5 \mathrm{~m}^{3}$ for the current cooling load is sufficient as solar fraction has no significant improvement by increasing the tank volume beyond this size. Actually, a relatively small storage tank is sufficient because we are operating the chiller only during the daytime, and in fact, a larger storage tank will have higher heat loss coefficients.

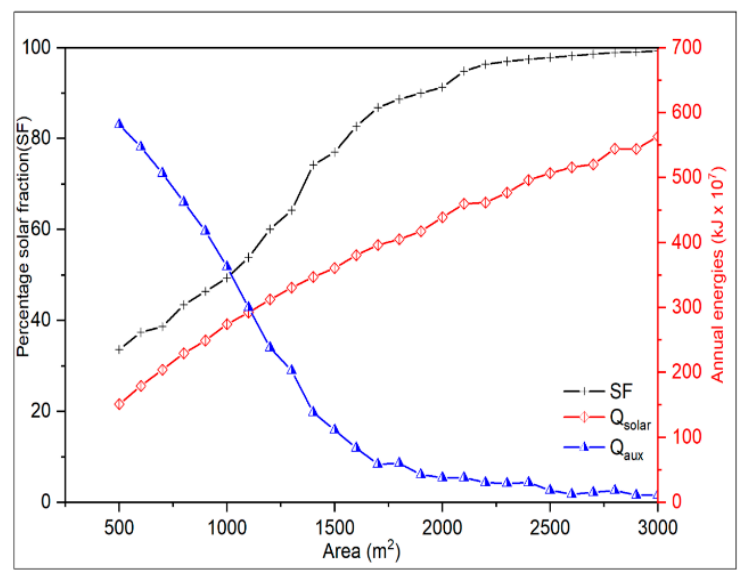

(a)

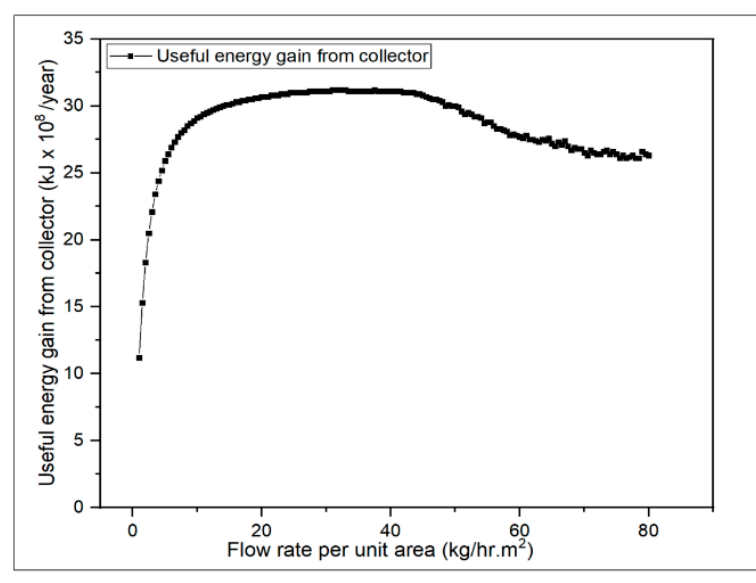

(b)

Figure 11. (a) Variation of solar fraction, solar and auxiliary energy by varying collector area; (b) the effect of mass flow rate on energy gain from collector $\left(\mathrm{Ac}=1000 \mathrm{~m}^{2}\right)$.

Another critical parameter for the performance of absorption chillers is the flow rate in the solar field. It is important to select a flow rate which on the one side consumes low electrical energy by the pump, and on the other hand maximizes the useful energy gain from the collector. Figure 11b illustrates the useful energy gain from the collector with respect to varying flow rates. The graph shows that increasing the flow rate in the solar loop increases the useful energy gain from the collectors. However, for flow rates greater than $50 \mathrm{~kg} / \mathrm{h} \mathrm{m}^{2}$, useful energy gain from the collectors starts decreasing. For larger flow rates we need a larger pump which will consume more energy. We found that collector flow rate in the range of $16-50 \mathrm{~kg} / \mathrm{h} \mathrm{m}^{2}$ is good for overall collector performance and these results are in good agreement with the literature [44].

Figure 11a shows that solar fraction increases with an increase in solar collector area. Figure 12a shows the effect of the solar collector area on annualized cost of ACS, and Figure 12b shows annualized running cost and associated emissions at different solar field sizes. It was found that at a lower solar fraction, more energy comes from the auxiliary source, which means large size of boiler and high 
consumption of fuel. The more consumption of fuel results in high running costs and more emissions. The selection of a suitable collector size and auxiliary boiler affects the annualized cost. For example, at a collector area of $500 \mathrm{~m}^{2}$ when solar fraction is only $33 \%$, the annualized cost of the system is $45.10 \times 10^{6}$ Pakistani rupees due to the large size of auxiliary boiler, and annualized running cost and associated emissions are $8.42 \times 10^{6}$ rupees and 575.4 tons of $\mathrm{CO}_{2}$ emissions, respectively. By increasing the solar collector area, solar fraction increases, which results in low auxiliary energy requirements (small size of boiler), lower annualized costs and associated emissions. At a collector area of 1700 to $2100 \mathrm{~m}^{2}$, the annualized cost of the system changes slightly because at this point the high cost of the solar field is compensated by a reduction in the capital cost of the auxiliary boiler (small size boiler is needed). However, selecting the collector area from 2100 to $3000 \mathrm{~m}^{2}$ results only in an $8 \%$ increase in solar fraction which shows that, though the size of boiler reduces marginally, the high cost of solar field results in an increase in annualized cost. Similarly, at a collector area of $2100 \mathrm{~m}^{2}$, annualized running cost is $3.53 \times 10^{6}$ rupees, which is 2.4 times less than for a collector area of $500 \mathrm{~m}^{2}$ and produces a similarly large reduction in $\mathrm{CO}_{2}$ emissions compared to a system with a collector area of $500 \mathrm{~m}^{2}$. Further, an increase in collector area does not significantly reduce the annualized running cost and emissions. Therefore, $2100 \mathrm{~m}^{2}$ is a suitable collector area in terms of reduction in annualized costs and $\mathrm{CO}_{2}$ emissions.

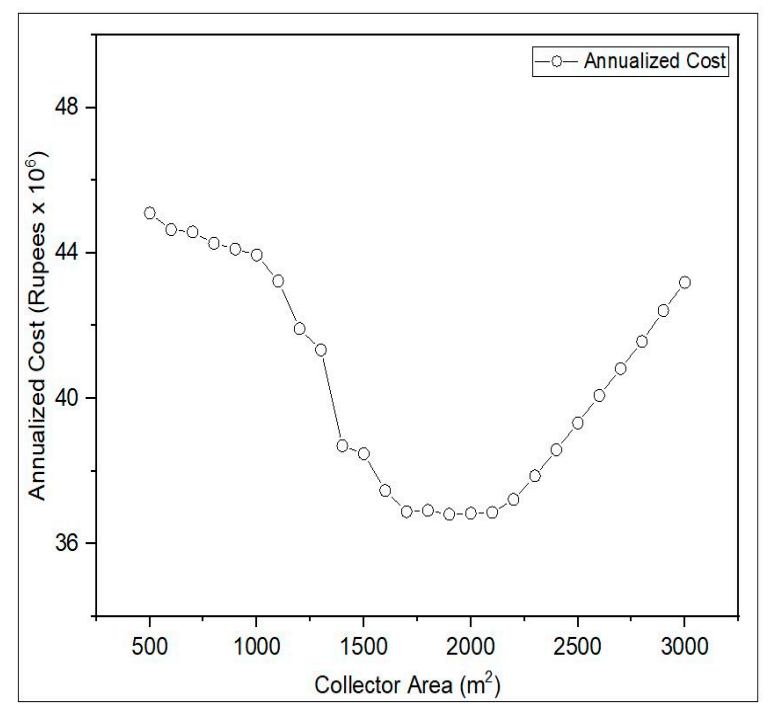

(a)

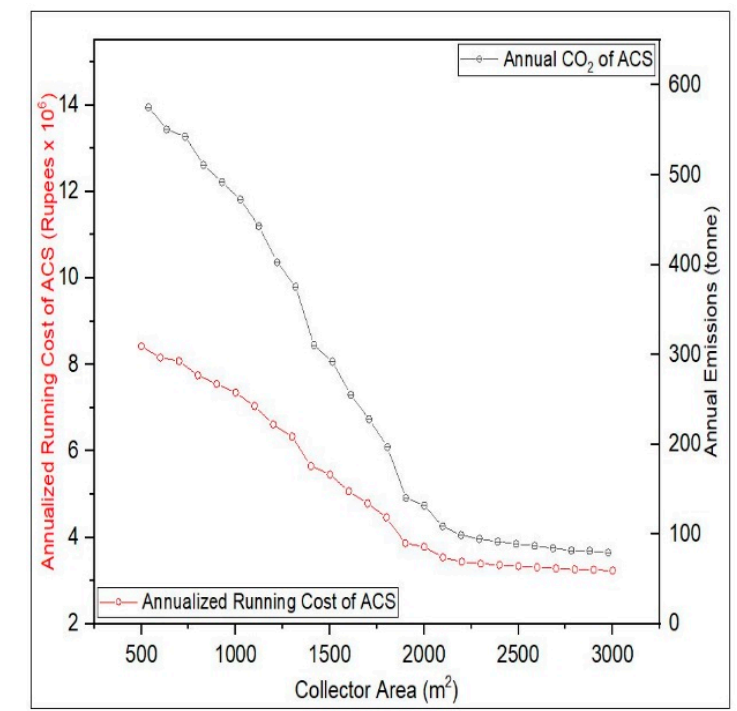

(b)

Figure 12. (a) Variation of annualized cost of ACS by varying collector area; (b) variation of annualized running cost and annual $\mathrm{CO}_{2}$ emissions of ACS by varying collector area.

To maximize the amount of solar irradiance on the collector surface, the tilt angle of the collector should be set carefully. Parametric results for the investigation of optimum collector tilt angles are shown in Figure 13a. The right axis of Figure 13a shows the variation of annual solar irradiance available at the collector surface by varying the tilt angle. The maximum annual solar irradiance is reached by setting the collector tilt angle to $31.5^{\circ}$. Setting the tilt angle greater than this reduced annual solar irradiance at the collector surface. Similarly, the variation of monthly solar irradiance as a function of tilt angle is shown for a few months on the left axis in Figure 13a. Parametric results for the monthly optimized angles are shown in Figure 13b. Results shows that monthly tilt angle varies from $61^{\circ}$ to $-7^{\circ}$ towards the south (negative sign means towards the north) throughout the year. Maximum solar irradiance is received at the collector in the winter season by setting the collector at higher tilt angles and at lower angles for the summer season. For peak summer season (May, June and July) when the sun rises in the northeast and sets in the northwest, the optimized tilt angle should be set as negative (towards the north). For the months of March and October, the optimized angle is almost 
equal to the latitude of the location. The performance of the collectors is also affected by orientation (azimuthal angle) of the collector throughout the year as this changes the amount of available solar energy at the collector surface. The variation of annual solar irradiance by changing collector position towards east ( 0 to 90 degree) or towards west ( 0 to -90 degree) is shown in Figure 14a. Parametric results for the optimum annual azimuthal position show that facing the equator ( 0 degrees) is the best collector orientation. Monthly variation of solar irradiance for a few months of the summer and winter seasons as a function of collector azimuthal angle is shown in Figure 14a as well. It is interesting to note that in the summer season, variation of monthly irradiance at collector surface by varying collector orientation is not significant, but this is more prominent in winter months.

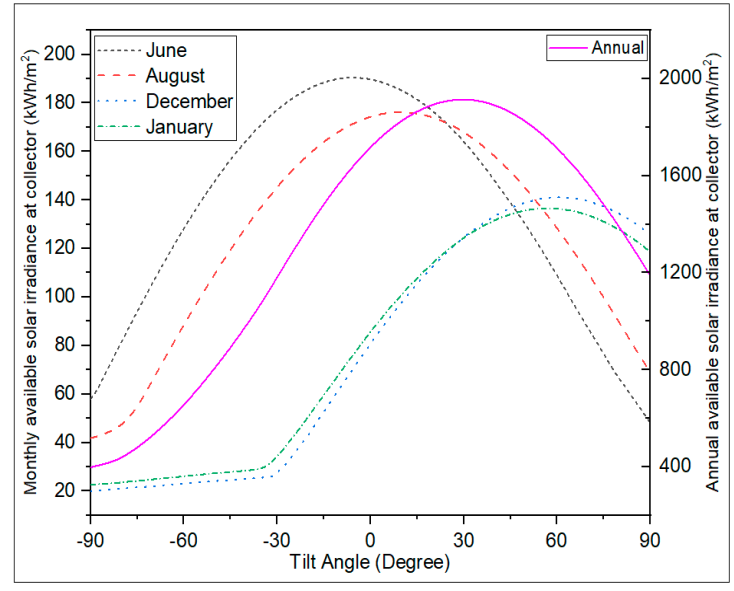

(a)

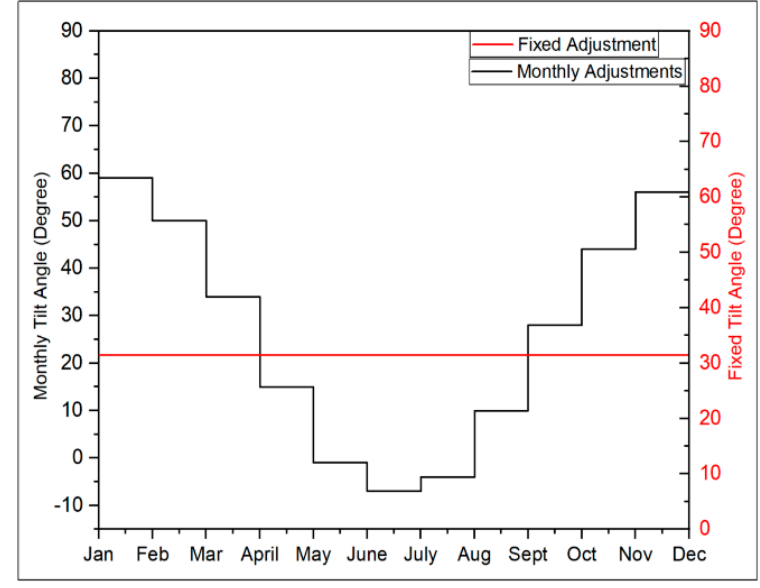

(b)

Figure 13. (a) Variation of solar irradiance as a function of collector tilt angle; (b) monthly optimized collector tilt angles.

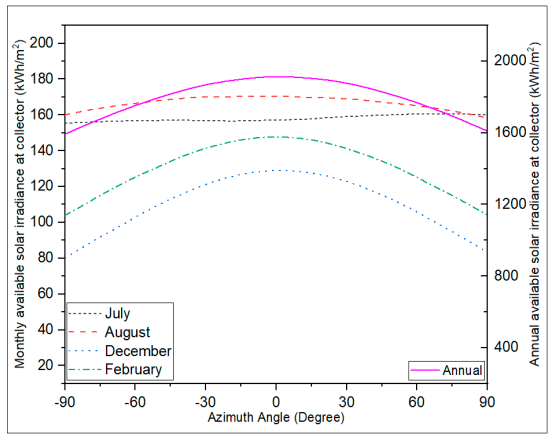

(a)

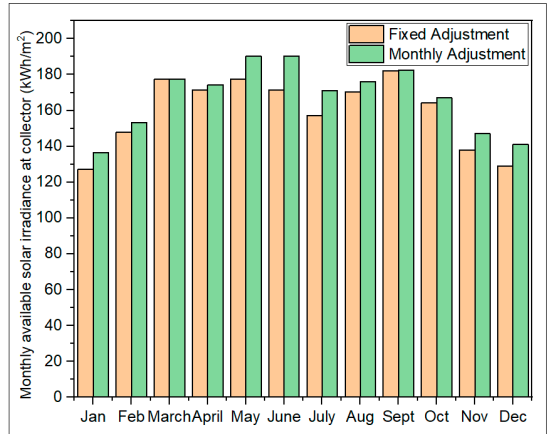

(b)

Figure 14. (a) Variation of solar irradiance as a function of collector orientation; (b) solar irradiance available at collector surface with fixed and monthly adjustment.

The benefits of setting the collector angle at the optimized annual and optimized monthly angles are shown in Figure 14b. The bar chart shows the amount of monthly available solar irradiance at the collector surface by setting it at the annual optimized angle and monthly optimized angles. It can be seen from the bar chart that minimum difference of energy gain with both adjustments is achieved in the months of March and September (because optimized angles for these months are close to the annual optimized angle) and the maximum difference lies in May, June and July. Results indicate that around $5 \%$ more solar irradiance is available per $\mathrm{m}^{2}$ of collector surface by adjusting the collector angles on a monthly basis compared to the annual optimized angle. By increasing the frequency of tilt adjustment of the collector on a fortnightly and daily basis improves the solar irradiance by $5.1 \%$ and $5.35 \%$, respectively. The improvement of solar irradiance for fortnightly and daily adjustment is 
marginal compared with monthly adjustments. So, instead of using an expensive tracking system, manual adjustment of the collector at optimized monthly angle is a good alternative option for thermal collectors.

\section{Conclusions}

In this study, two different cooling systems, vapour compression-cycle based (water-cooled chiller) and thermal-driven based (solar-driven vapour absorption chiller) were studied. Electricity from a national grid was used to drive the compressor of the water-cooled vapour compression chiller while the evacuated tube collector and/or auxiliary gas boiler were used to supply hot water to drive the absorption chiller. A large industrial building was modelled in TRNSYS TRNBuild as a reference case to calculate hourly and peak cooling load for the design of both systems. Based on peak cooling load, both systems were modelled in TRNSYS and were compared energetically, economically and environmentally for the climate of Lahore, Pakistan. In addition, to perform a parametric study a parametric code was written in Python and coupled to the TRNSYS simulation model of the solar-driven absorption chiller. Main parameters affecting the performance of absorption chillers such as collector area, storage tank volume, flow rate in solar field, solar collector annual and monthly optimized tilt and azimuthal angles were investigated. The following conclusions can be drawn:

(1) At the current discount rate for Pakistan, the comparison of solar thermal and electric cooling technologies showed that the levelized capital cost of solar-absorption chillers is about three times higher than for conventional water-cooled chillers. The cost of the ACS system depends on selection of collector area and boiler for auxiliary energy requirements. On the other hand, the running cost of the solar-driven ACS is 4.1-times lower than for the water-cooled VCC. It was found that 3.19-times less $\mathrm{CO}_{2}$ emissions will be produced annually by using a solar-driven vapour absorption chiller for the selected building instead of an electrically driven water-cooled vapour compression chiller. In the case of using a solar-driven vapour absorption chiller to fulfil cooling needs of the selected building archetype, $1.65 \times 10^{6} \mathrm{kWh}$ of primary energy can be saved annually.

(2) The parametric study results indicate that solar fraction increases with increasing collector area, but the rate of increase of solar fraction decreases at higher collector areas. The rate of increase of solar fraction above an optimum collector area is not significant. There is no strong dependence between solar fraction and storage tank volume for the tested system. This is most likely due to the daytime only operation of the system so that a small storage tank is sufficient to balance solar resource and demand differences.

(3) Another critical parameter that affects the performance of solar collectors is flow rate in the solar collector loop. It is found that increasing the flow rate results in higher useful energy gain and higher collector efficiency. The parametric study shows that the mass flow per unit collector area for optimal collector performance lies in the range of $16-50 \mathrm{~kg} / \mathrm{h} \mathrm{m}^{2}$. For higher flowrates, collector yield decreases and it also results in higher energy consumption of pumps.

(4) To maximize the amount of solar irradiance on the collector surface, collector tilt (slope) angle and azimuthal angle with annual optimum fixed adjustment and monthly adjustments were investigated. It was found that adjusting the collector tilt on a monthly basis results in 5\% more solar irradiance per $\mathrm{m}^{2}$ of collector surface with respect to annual optimum fixed adjustment. Further, increasing the collector tilt angle adjustment frequency on a fortnightly and daily basis results in $5.1 \%$ and $5.35 \%$ more solar irradiance per unit collector area compared to annual fixed adjustment, as increasing the frequency of slope adjustment from monthly to fortnightly or daily marginally increased the solar irradiance. It is beneficial to adjust collector slope on a monthly basis. Maximum solar irradiance is received at the collector surface in the winter season by setting the collector at higher tilt angles and at lower angles for the summer season. 
Overall, in this paper, energetic, economic and environmental performance of two different cooling technologies, i.e., water-cooled vapour compression system and solar-driven vapour absorption system, were compared. Critical parameters affecting the performance of the solar-driven ACS system such as solar field size, flow rate in solar collector loop, storage tank volume, annual optimum fixed angle and monthly optimized angles for solar thermal collectors are presented, which will be useful for readers who work in solar-driven cooling systems.

Author Contributions: Conceptualization, S.M. and D.F.; methodology, S.M. and D.F.; software, S.M. and S.A.M.; validation, S.M. and S.A.M.; formal analysis, S.M. and D.F.; data curation, S.M.; writing—original draft preparation, S.M.; writing-review and editing, S.M., S.A.M., H.C. and D.F.; visualization, S.M.; supervision, H.C. and D.F.; project administration, D.F.; funding acquisition, S.M., S.A.M. and D.F. All authors have read and agreed to the published version of the manuscript.

Funding: This research received no external funding.

Acknowledgments: Sajid Mehmood acknowledges the support from Higher Education Commission (HEC), Pakistan in the form of PhD scholarship and University of Engineering and Technology, Lahore, Pakistan for study leave. Serguey A. Maximov acknowledges the support from National Agency for Research and Development (ANID), Chile in terms of PhD scholarship.

Conflicts of Interest: The authors declare no conflict of interest.

\section{Nomenclature}

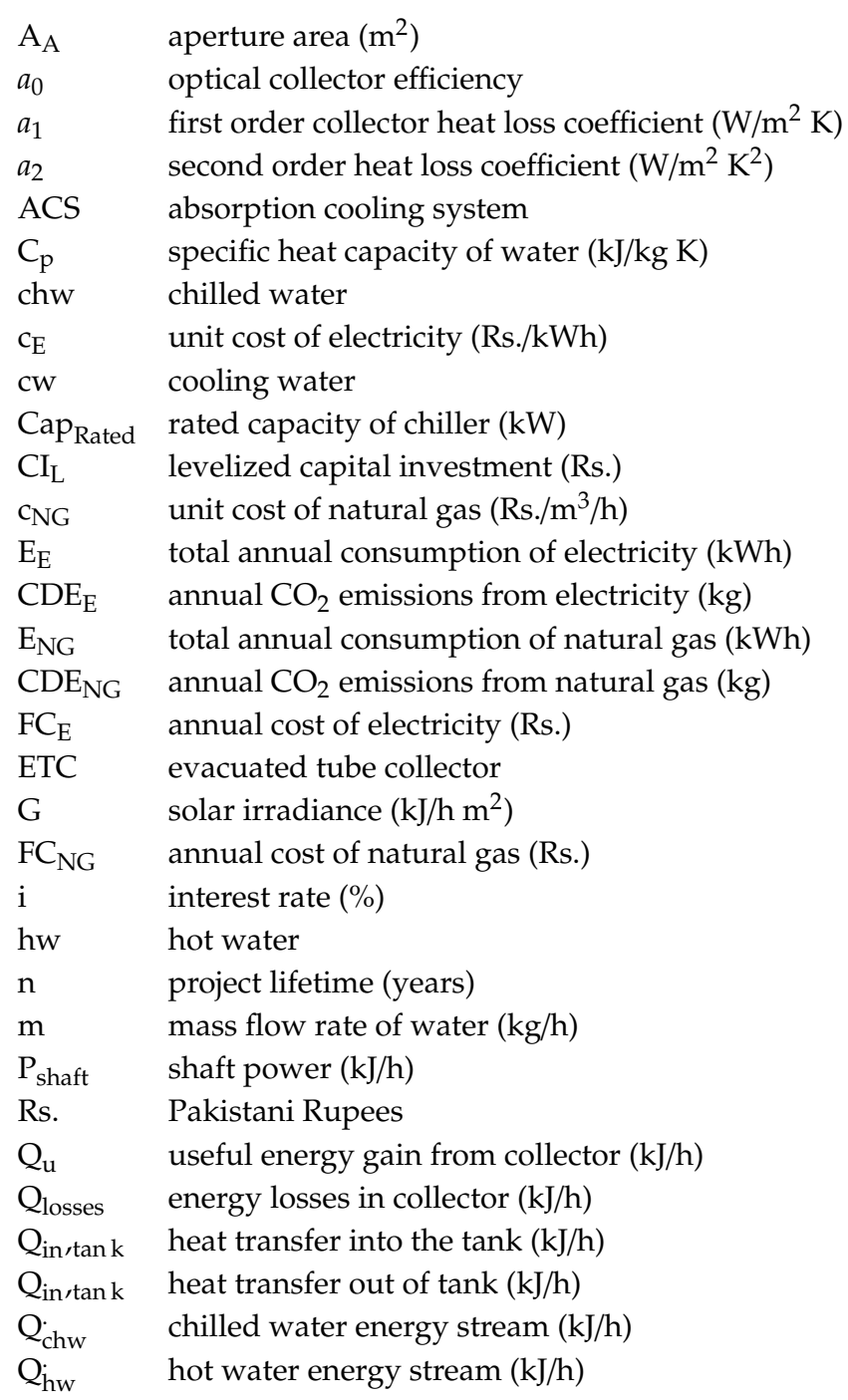




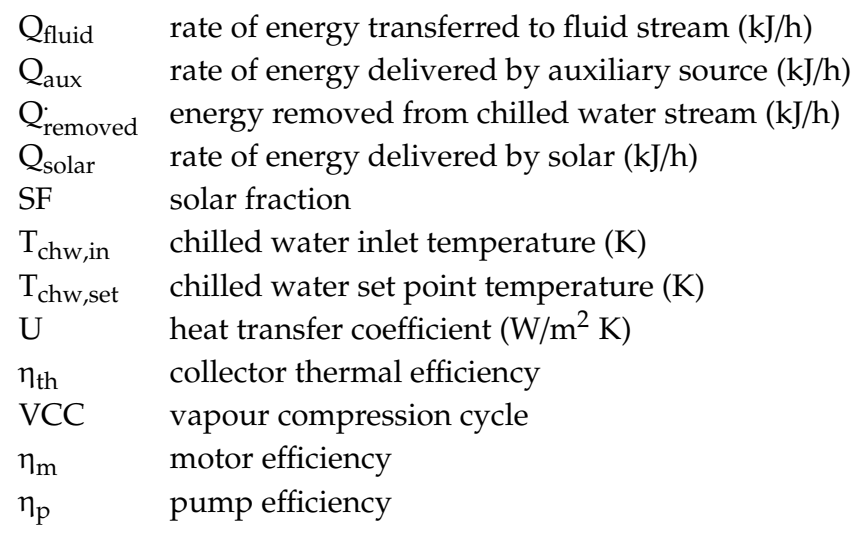

\section{References}

1. Kibria, A.; Akhundjanov, S.B.; Oladi, R. Fossil fuel share in the energy mix and economic growth. Int. Rev. Econ. Financ. 2019, 59, 253-264. [CrossRef]

2. Baz, K.; Xu, D.; Ampofo, G.M.K.; Ali, I.; Khan, I.; Cheng, J.; Ali, H. Energy consumption and economic growth nexus: New evidence from Pakistan using asymmetric analysis. Energy 2019, 189, 116254. [CrossRef]

3. Shahid, M.; Ullah, K.; Imran, K.; Mahmood, I.; Mahmood, A. Electricity supply pathways based on renewable resources: A sustainable energy future for Pakistan. J. Clean. Prod. 2020, 263, 121511. [CrossRef]

4. Flores-Chamba, J.; López-Sánchez, M.; Ponce, P.; Guerrero-Riofrío, P.; Álvarez-García, J. Economic and spatial determinants of energy consumption in the European union. Energies 2019, 12, 4118. [CrossRef]

5. Akbar, U.; Popp, J.; Khan, H.; Khan, M.A.; Oláh, J. Energy Efficiency in Transportation along with the Belt and Road Countries. Energies 2020, 13, 2067. [CrossRef]

6. Talbi, B.; Nguyen, D.K. An empirical analysis of energy demand in Tunisia. Econ. Bull. 2014, 34, 452-458.

7. O'Connor, D.; Calautit, J.K.; Hughes, B.R. A novel design of a desiccant rotary wheel for passive ventilation applications. Appl. Energy 2016, 179, 99-109. [CrossRef]

8. Shirazi, A.; Taylor, R.A.; Morrison, G.L.; White, S.D. Solar-powered absorption chillers: A comprehensive and critical review. Energy Convers. Manag. 2018, 171, 59-81. [CrossRef]

9. She, X.; Cong, L.; Nie, B.; Leng, G.; Peng, H.; Chen, Y.; Zhang, X.; Wen, T.; Yang, H.; Luo, Y. Energy-efficient and -economic technologies for air conditioning with vapor compression refrigeration: A comprehensive review. Appl. Energy 2018, 232, 157-186. [CrossRef]

10. Henning, H.; Motta, M.; Mugnier, D. Solar Cooling Handbook, 3rd ed.; TEcSol, F., Ed.; AMBRA/V: Vienna, Austria, 2013; ISBN 9783990434383.

11. Henning, H.M. Solar assisted air conditioning of buildings-An overview. Appl. Therm. Eng. 2007, 27, 1734-1749. [CrossRef]

12. International Energy Agency (IEA). Technology Roadmap Solar Heating and Cooling. Available online: https://www.iea.org/publications/freepublications/\%0Apublication/Solar_Heating_Cooling_Roadmap_201 2_WEB.pdf (accessed on 21 July 2020).

13. Alternative Energy Development Board. Available online: http://www.aedb.org/ae-technologies/solar-pow er/solar-resources (accessed on 6 April 2019).

14. Chen, J.F.; Dai, Y.J.; Wang, R.Z. Experimental and analytical study on an air-cooled single effect $\mathrm{LiBr}-\mathrm{H} 2 \mathrm{O}$ absorption chiller driven by evacuated glass tube solar collector for cooling application in residential buildings. Sol. Energy 2017, 151, 110-118. [CrossRef]

15. Bi, Y.; Qin, L.; Guo, J.; Li, H.; Zang, G. Performance analysis of solar air conditioning system based on the independent-developed solar parabolic trough collector. Energy 2020, 196, 117075. [CrossRef]

16. Zheng, X.; Shi, R.; Wang, Y.; You, S.; Zhang, H.; Xia, J.; Wei, S. Mathematical modeling and performance analysis of an integrated solar heating and cooling system driven by parabolic trough collector and double-effect absorption chiller. Energy Build. 2019, 202, 109400. [CrossRef]

17. Al-Alili, A.; Hwang, Y.; Radermacher, R.; Kubo, I. A high efficiency solar air conditioner using concentrating photovoltaic/thermal collectors. Appl. Energy 2012, 93, 138-147. [CrossRef] 
18. Buonomano, A.; Calise, F.; D’Accadia, M.D.; Ferruzzi, G.; Frascogna, S.; Palombo, A.; Russo, R.; Scarpellino, M. Experimental analysis and dynamic simulation of a novel high-temperature solar cooling system. Energy Convers. Manag. 2016, 109, 19-39. [CrossRef]

19. Xu, Z.Y.; Wang, R.Z. Comparison of CPC driven solar absorption cooling systems with single, double and variable effect absorption chillers. Sol. Energy 2017, 158, 511-519. [CrossRef]

20. Gomri, R. Simulation study on the performance of solar/natural gas absorption cooling chillers. Energy Convers. Manag. 2013, 65, 675-681. [CrossRef]

21. Khan, M.S.A.; Badar, A.W.; Talha, T.; Khan, M.W.; Butt, F.S. Configuration based modeling and performance analysis of single effect solar absorption cooling system in TRNSYS. Energy Convers. Manag. 2018, 157, 351-363. [CrossRef]

22. Al-Ugla, A.A.; El-Shaarawi, M.A.I.; Said, S.A.M.; Al-Qutub, A.M. Techno-economic analysis of solar-assisted air-conditioning systems for commercial buildings in Saudi Arabia. Renew. Sustain. Energy Rev. 2016, 54, 1301-1310. [CrossRef]

23. THOMSON REUTERS FOUNDATION NEWS. Available online: https://news.trust.org/item/20130625141050 -sw1nq/ (accessed on 14 September 2019).

24. TRNSYS. Available online: http://www.trnsys.com/ (accessed on 9 February 2019).

25. SketchUp. Available online: https://www.sketchup.com/industries/architecture (accessed on 24 March 2019).

26. Herrando, M.; Pantaleo, A.M.; Wang, K.; Markides, C.N. Solar combined cooling, heating and power systems based on hybrid PVT, PV or solar-thermal collectors for building applications. Renew. Energy 2019, 143, 637-647. [CrossRef]

27. ASHRAE. Available online: https://ashrae.iwrapper.com/ViewOnline/Standard_90.2-2018 (accessed on 5 June 2019).

28. VIESSMANN. Available online: http://www.viessmann-us.com/content/dam/internet-ca/pdfs/solar/vitosol_ 200-t_spe_tdm.pdf (accessed on 15 June 2019).

29. Trnsys 18: A TRaNsient SYstem Simulation program. Sol. Energy Lab. Univ. Wis. Madison Math. Ref. 2018, 4,705 .

30. ASHRAE. Solar Collectors and Photovoltaic in EnergyPRO; ASHRAE: Peachtree Corners, GA, USA, 2013; pp. 1-23.

31. Han, Y.M.; Wang, R.Z.; Dai, Y.J. Thermal stratification within the water tank. Renew. Sustain. Energy Rev. 2009, 13, 1014-1026. [CrossRef]

32. Khankari, G.; Munda, J.; Karmakar, S. Power Generation from Condenser Waste Heat in Coal-fired Thermal Power Plant Using Kalina Cycle. Energy Procedia 2016, 90, 613-624. [CrossRef]

33. Munwir, A.; Damson Consulting Engineers, Lahore, Pakistan. Personal communication, 2020.

34. The University of WISCONSIN. Available online: https://sel.me.wisc.edu/trnsys/validation/index.html (accessed on 2 February 2020).

35. Energy Efficiency \& Renewable Energy. Available online: https://www.energy.gov/eere/buildings/ashrae-sta ndard-140-maintenance-and-development (accessed on 21 July 2020).

36. Puig-Arnavat, M.; López-Villada, J.; Bruno, J.C.; Coronas, A. Analysis and parameter identification for characteristic equations of single- and double-effect absorption chillers by means of multivariable regression. Int. J. Refrig. 2010, 33, 70-78. [CrossRef]

37. Kühn, A.; Ziegler, F. Operational results of a $10 \mathrm{~kW}$ absorption chiller and adaptation of the characteristic equation. Proc. First Int. Conf. Sol. Air Cond. 2005, 10, 5-9.

38. Broad X Non-Electric Chiller: Model Selection \& Design Manual. Available online: https://www.broadusa.n et/en/wp-content/uploads/2015/03/Broad-X-chiller-Model-selection-design-manual-C.pdf (accessed on 6 January 2020).

39. State Bank of Pakistan. Economic Data. Available online: http://www.sbp.org.pk/ecodata/index2.asp (accessed on 24 December 2019).

40. National Electric Power Regulatory Authority. LESCO. Available online: https://nepra.org.pk/tariff/Distribu tionLESCO.php (accessed on 24 December 2019).

41. Sui Northern Gas Pipelines Ltd. Consumer Gas Prices. Available online: https://www.sngpl.com.pk/ (accessed on 24 December 2019).

42. Yousuf, I.; Ghumman, A.R.; Hashmi, H.N.; Kamal, M.A. Carbon emissions from power sector in Pakistan and opportunities to mitigate those. Renew. Sustain. Energy Rev. 2014, 34, 71-77. [CrossRef] 
43. Central Power Purchasing Agency. Available online: http://www.cppa.gov.pk/Home/DownloadDetails?Typ e=AnnualReports (accessed on 2 February 2020).

44. Ko, M.J. A novel design method for optimizing an indirect forced circulation solar water heating system based on life cycle cost using a genetic algorithm. Energies 2015, 8, 11592-11617. [CrossRef]

(C) 2020 by the authors. Licensee MDPI, Basel, Switzerland. This article is an open access article distributed under the terms and conditions of the Creative Commons Attribution (CC BY) license (http://creativecommons.org/licenses/by/4.0/). 